\title{
Identifying fire plumes in the Arctic with tropospheric FTIR measurements and transport models
}

\author{
C. Viatte ${ }^{1, *}$, K. Strong ${ }^{1}$, J. Hannigan ${ }^{2}$, E. Nussbaumer ${ }^{2}$, L. K. Emmons ${ }^{2}$, S. Conway ${ }^{1}$, C. Paton-Walsh ${ }^{3}$, J. Hartley ${ }^{1}$, \\ J. Benmergui ${ }^{4, * *}$, and J. Lin $^{4,5}$ \\ ${ }^{1}$ Department of Physics, University of Toronto, Toronto, ON, Canada \\ ${ }^{2}$ National Center for Atmospheric Research, Boulder, CO, USA \\ ${ }^{3}$ Department of Chemistry, University of Wollongong, Wollongong, New South Wales, Australia \\ ${ }^{4}$ Department of Earth and Environmental Sciences, University of Waterloo, Waterloo, ON, Canada \\ ${ }^{5}$ Department of Atmospheric Sciences, University of Utah, Salt Lake City, UT, USA \\ *now at: Division of Geological and Planetary Sciences, California Institute of Technology, Pasadena, CA, USA \\ ***now at: School of Engineering and Applied Sciences, Harvard University, Cambridge, MA, USA
}

Correspondence to: C. Viatte (viatte@atmosp.physics.utoronto.ca) and K. Strong (strong@ atmosp.physics.utoronto.ca)

Received: 9 August 2014 - Published in Atmos. Chem. Phys. Discuss.: 21 October 2014

Revised: 28 January 2015 - Accepted: 30 January 2015 - Published: 2 March 2015

\begin{abstract}
We investigate Arctic tropospheric composition using ground-based Fourier transform infrared (FTIR) solar absorption spectra, recorded at the Polar Environment Atmospheric Research Laboratory (PEARL, Eureka, Nunavut, Canada, $80^{\circ} 05^{\prime} \mathrm{N}, 86^{\circ} 42^{\prime} \mathrm{W}$ ) and at Thule (Greenland, $76^{\circ} 53^{\prime} \mathrm{N},-68^{\circ} 74^{\prime} \mathrm{W}$ ) from 2008 to 2012 . The target species, carbon monoxide $(\mathrm{CO})$, hydrogen cyanide $(\mathrm{HCN})$, ethane $\left(\mathrm{C}_{2} \mathrm{H}_{6}\right)$, acetylene $\left(\mathrm{C}_{2} \mathrm{H}_{2}\right)$, formic acid $(\mathrm{HCOOH})$, and formaldehyde $\left(\mathrm{H}_{2} \mathrm{CO}\right)$ are emitted by biomass burning and can be transported from mid-latitudes to the Arctic.

By detecting simultaneous enhancements of three biomass burning tracers $\left(\mathrm{HCN}, \mathrm{CO}\right.$, and $\left.\mathrm{C}_{2} \mathrm{H}_{6}\right)$, ten and eight fire events are identified at Eureka and Thule, respectively, within the 5-year FTIR time series. Analyses of Hybrid Single Particle Lagrangian Integrated Trajectory (HYSPLIT) model back-trajectories coupled with Moderate Resolution Imaging Spectroradiometer (MODIS) fire hotspot data, Stochastic Time-Inverted Lagrangian Transport (STILT) model footprints, and Ozone Monitoring Instrument (OMI) UV aerosol index maps, are used to attribute burning source regions and travel time durations of the plumes. By taking into account the effect of aging of the smoke plumes, measured FTIR enhancement ratios were corrected to obtain emission ratios and equivalent emission factors. The means of emission factors for extratropical forest estimated with the two FTIR data sets are $0.40 \pm 0.21 \mathrm{~g} \mathrm{~kg}^{-1}$ for $\mathrm{HCN}, 1.24 \pm 0.71 \mathrm{~g} \mathrm{~kg}^{-1}$ for
\end{abstract}

$\mathrm{C}_{2} \mathrm{H}_{6}, 0.34 \pm 0.21 \mathrm{~g} \mathrm{~kg}^{-1}$ for $\mathrm{C}_{2} \mathrm{H}_{2}$, and $2.92 \pm 1.30 \mathrm{~g} \mathrm{~kg}^{-1}$ for $\mathrm{HCOOH}$. The emission factor for $\mathrm{CH}_{3} \mathrm{OH}$ estimated at Eureka is $3.44 \pm 1.68 \mathrm{~g} \mathrm{~kg}^{-1}$.

To improve our knowledge concerning the dynamical and chemical processes associated with Arctic pollution from fires, the two sets of FTIR measurements were compared to the Model for OZone And Related chemical Tracers, version 4 (MOZART-4). Seasonal cycles and day-to-day variabilities were compared to assess the ability of the model to reproduce emissions from fires and their transport. Good agreement in winter confirms that transport is well implemented in the model. For $\mathrm{C}_{2} \mathrm{H}_{6}$, however, the lower wintertime concentration estimated by the model as compared to the FTIR observations highlights an underestimation of its emission. Results show that modeled and measured total columns are correlated (linear correlation coefficient $r>0.6$ for all gases except for $\mathrm{H}_{2} \mathrm{CO}$ at Eureka and $\mathrm{HCOOH}$ at Thule), but suggest a general underestimation of the concentrations in the model for all seven tropospheric species in the high Arctic.

\section{Introduction}

Fires release trace gases into the atmosphere, affecting air quality (Colarco et al., 2004), climate, and the carbon cycle (IPCC, 2007). Those radiatively and photochem- 
ically active trace gases include carbon monoxide (CO), hydrogen cyanide $(\mathrm{HCN})$, and non-methane hydrocarbons (NMHCs), including ethane $\left(\mathrm{C}_{2} \mathrm{H}_{6}\right)$, acetylene $\left(\mathrm{C}_{2} \mathrm{H}_{2}\right)$, methanol $\left(\mathrm{CH}_{3} \mathrm{OH}\right)$, formic acid $(\mathrm{HCOOH})$, and formaldehyde $\left(\mathrm{H}_{2} \mathrm{CO}\right)$ (Paton-Walsh et al., 2010; Akagi et al., 2011; Vigouroux et al., 2012). Given their long atmospheric lifetimes, $\mathrm{CO}, \mathrm{HCN}$, and $\mathrm{C}_{2} \mathrm{H}_{6}$ are considered to be tracers of long-range pollution transport associated with biomass burning plumes. In the Arctic, these gases and the other shorterlived species $\left(\mathrm{C}_{2} \mathrm{H}_{2}, \mathrm{CH}_{3} \mathrm{OH}, \mathrm{HCOOH}\right.$, and $\left.\mathrm{H}_{2} \mathrm{CO}\right)$ affect the tropospheric chemistry (Generoso et al., 2007, Stohl et al., 2007, Tilmes et al., 2011), oxidizing power (Mao et al., 2010; Olson et al., 2012), and radiative transfer (Wang et al., 2011) of this sensitive polar region, which has been warming rapidly over the past century (Lesins et al., 2010). Since fire frequency and intensity are sensitive to climate change and variability, as well as land use practices (Kasischke et al., 2006; Soja et al., 2007; IPCC, 2007; Amiro et al., 2009; Flannigan et al., 2009; Oris et al., 2013; Kelly et al., 2013), they constitute a large source of variability in Arctic tropospheric composition.

Biomass burning plumes transported over the Arctic have been observed by ground-based Fourier transform infrared (FTIR) spectrometers (Yurganov et al., 2004, 2005; Viatte et al., 2013), measurements on aircraft (Paris et al., 2009; Warneke et al., 2009; Simpson et al., 2011; Hecobian et al., 2011; Parrington et al., 2013; O'Shea et al., 2013; Le Breton et al., 2013; Lewis et al., 2013), and satellites (Rinsland et al., 2007; Coheur et al., 2009; Tereszchuk et al., 2011, 2013). Model simulations and meteorological analyses also suggest pollution transport pathways to the Arctic (Eckhardt et al., 2003; Klonecki et al., 2003; Koch and Hansen, 2005; Stohl et al., 2006; Shindell et al., 2008; Thomas et al., 2013; Bian et al., 2013). However, our knowledge concerning transport, degradation mechanisms of NMHCs (Stavrakou et al., 2009), sources of Arctic pollution (Fisher et al., 2010), and emissions from fires (Akagi et al., 2011), remains incomplete, reflecting the heterogeneous and stochastic nature of these processes. Long-term and continuous measurements of Arctic tropospheric composition are therefore important for quantifying emissions from fire plumes transported from lower latitudes and improving the prediction of trace gas concentrations and variability in chemical transport model simulations. This would help in assessing the atmospheric impact of biomass burning pollution on the Arctic climate system.

To simulate fire emissions in chemical transport models, emission factors of various trace gases must be estimated with accuracy. Emission factors are highly variable however, because they depend on the types of vegetation burned, the combustion phase (smoldering and flaming), and atmospheric conditions at the time of the fire events (Paton-Walsh et al., 2005, 2008, 2010; Akagi et al., 2011; Hornbrook et al., 2011; Vigouroux et al., 2012). Within the past decade, measurements of emission factors of biomass burning species have led to a wide range of values, which may be due to

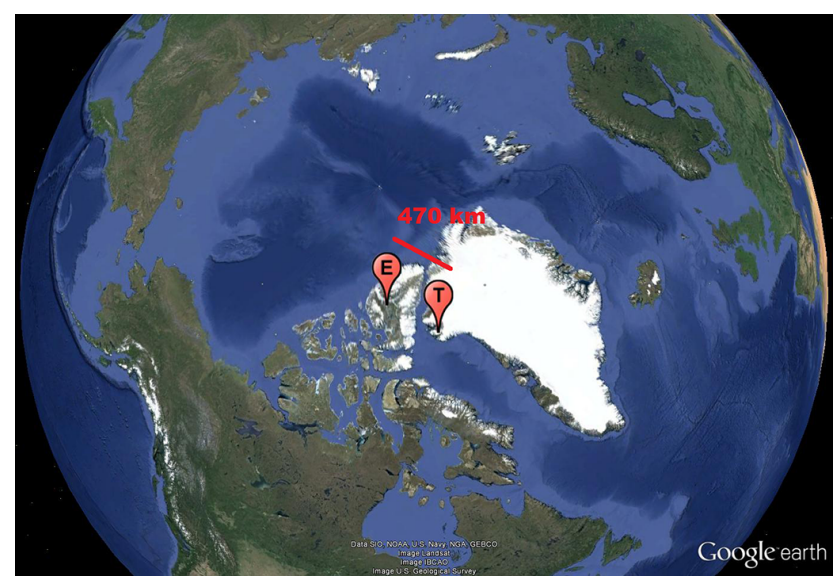

Figure 1. Locations of the FTIR measurements at Eureka (E) and Thule (T) (map provided by GOOGLE EARTH V 7.0.3.8542, US Dept. of State Geographer, Google, 2012, Image Landsat, Data SIO, NOAA, US, Navy, NGA, and GEBCO).

the natural variability of the emissions and/or the discrepancies between sampling methods (laboratory, airborne, satellite, and ground-based measurements) that overestimate or underestimate the combustion phases (smoldering and flaming). The need for more measurements of $\mathrm{HCN}$ and NMHC emission factors has been stressed given the value of HCN as a biomass burning tracer ( $\mathrm{Li}$ et al., 2003) and significant NMHC emissions from fires (Andreae and Merlet, 2001; Akagi et al., 2011; Paulot et al., 2011; Wiedinmyer et al., 2011).

We investigate pollution from biomass burning events that occurred in extratropical forests and were transported to the high Arctic with two sets of FTIR measurements, located at Eureka (Nunavut, Canada, $80^{\circ} 05^{\prime} \mathrm{N},-86^{\circ} 42^{\prime} \mathrm{W}$ ) and Thule (Greenland, $76^{\circ} 53^{\prime} \mathrm{N},-68^{\circ} 74^{\prime} \mathrm{W}$ ). Seven tropospheric species ( $\mathrm{CO}, \mathrm{HCN}, \mathrm{C}_{2} \mathrm{H}_{6}, \mathrm{C}_{2} \mathrm{H}_{2}, \mathrm{CH}_{3} \mathrm{OH}, \mathrm{HCOOH}$, and $\mathrm{H}_{2} \mathrm{CO}$ ) released by biomass burning were monitored from 2008 to 2012. Complete descriptions of the methodologies and characterizations of the retrievals are found in Viatte et al. (2014). These species were selected because of their differing anthropogenic, biogenic, fossil fuel burning and biomass burning source fractions, as well as their widely differing lifetimes, sinks, and secondary production rates. From this diversity, we gain insight into chemistry and transport abilities of the Model for OZone And Related chemical Tracers, version 4 (MOZART-4, Emmons et al., 2010) and improve emission ratios. A significant number of observations inside fire plumes are identified in the data sets and used to derive emission ratios (and hence infer emission factors) of the target species. These measured emission ratios add new values to the sparse data set reported in the literature. The two sets of measurements are compared with MOZART-4 to assess the ability of this model to reproduce Arctic tropospheric chemical composition and its variability due to the long-range pollution transport from fires. 


\section{Observations and model data in the high Arctic}

\subsection{FTIR measurements at Eureka and Thule}

We present measurements over 5 years of 7 tropospheric species in the high Arctic, $\mathrm{CO}, \mathrm{HCN}, \mathrm{C}_{2} \mathrm{H}_{6}, \mathrm{C}_{2} \mathrm{H}_{2}, \mathrm{CH}_{3} \mathrm{OH}$, $\mathrm{HCOOH}$, and $\mathrm{H}_{2} \mathrm{CO}$, from 2008 to 2012. These time series are obtained from ground-based FTIR measurements performed at Eureka $\left(80^{\circ} 05^{\prime} \mathrm{N}, 86^{\circ} 42^{\prime} \mathrm{W}, 0.61 \mathrm{~km}\right.$ a.s.l., Eureka, Nunavut, Canada, Fogal et al., 2013) and Thule $\left(76^{\circ} 53^{\prime} \mathrm{N},-68^{\circ} 74^{\prime} \mathrm{W}, 0.23 \mathrm{~km}\right.$ a.s.l., Greenland, Thule, Hannigan et al., 2009). The locations of the measurement sites are shown in Fig. 1. The high-resolution solar absorption spectrometers (a Bruker IFS 125HR at Eureka and a Bruker IFS $120 \mathrm{M}$ at Thule, both operated at a spectral resolution of $0.0035 \mathrm{~cm}^{-1}$ ) are part of the international Network for the Detection of Atmospheric Composition Change (NDACC, http://www.ndsc.ncep.noaa.gov/, formerly NDSC, Kurylo, 1991; Kurylo and Zander 2001). These spectrometers measure spectra using two detectors (indium antimonide - InSb - or mercury cadmium telluride - MCT), a potassium bromide $(\mathrm{KBr})$ beamsplitter, and a sequence of seven and eight narrow-band interference filters covering the 600 $4300 \mathrm{~cm}^{-1}$ and $750-5000 \mathrm{~cm}^{-1}$ spectral ranges, at Eureka and Thule, respectively. A reference low-pressure hydrogen bromide $(\mathrm{HBr})$ cell spectrum is recorded regularly with an internal globar source to characterize the instrument line shape (ILS) and monitor alignment of both instruments (Coffey et al. 1998). By using the LINEFIT software analysis (Hase et al., 1999), modulation efficiency and phase error are retrieved and can be included in the retrieval analysis (i.e., forward model).

In order to retrieve concentrations of these species from the recorded spectra, the optimal estimation method (OEM, Rodgers, 2000) has been applied using the new SFIT4 retrieval code (https://wiki.ucar.edu/display/sfit4/Infrared+ Working+Group+Retrieval+Code,+SFIT). With the exception of the ILS and signal-to-noise ratio (SNR), which are specific to each instrument, we use the same methodology to analyze the Eureka and Thule measurements, i.e., homogenized micro-windows, the same spectroscopic parameters from the HITRAN 2008 database (Rothman et al., 2009), and the same a priori covariance matrices. For $\mathrm{CO}, \mathrm{HCN}$, and $\mathrm{C}_{2} \mathrm{H}_{6}$, retrieval parameters are based on the NDACC-IRWG standard parameter definitions (NDACC Infrared Working Group, http://www.acd.ucar.edu/irwg/). Details of the retrievals of the seven tropospheric species at Eureka are described in Viatte et al. (2014). A priori profiles of the target species are derived from the mean of 40 year runs from the Whole Atmosphere Community Climate Model, version 6 (WACCM, http://www2.cesm.ucar. edu/working-groups, Garcia et al., 2007; Eyring et al., 2007), for the two stations. Daily pressure and temperature profiles are from the National Center for Environment Prediction (NCEP, http://www.ncep.noaa.gov/). Monthly a priori water
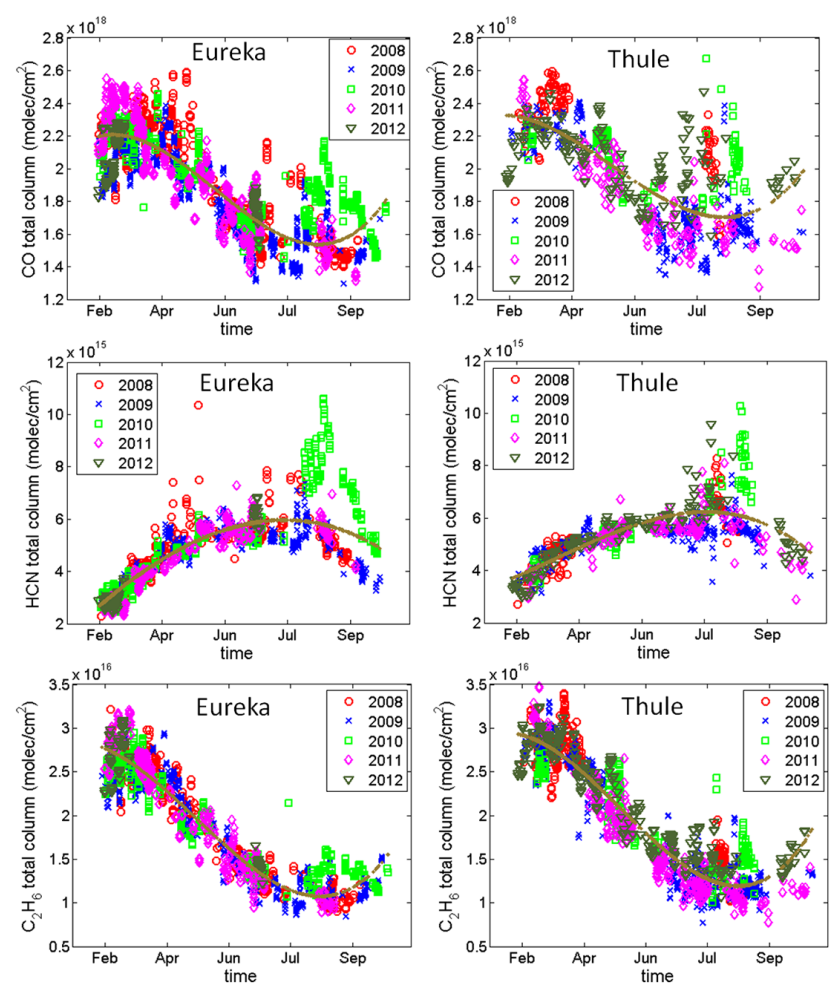

Figure 2. Time series of $\mathrm{CO}, \mathrm{HCN}$, and $\mathrm{C}_{2} \mathrm{H}_{6}$ total columns measured at Eureka (left panels) and Thule (right panels) from 2008 to 2012. The brown lines represent the polynomial fits to the data.

vapor profiles are taken from the WACCM output for each location. Our profiles are retrieved on 48 level altitude grids (from 0.61 to $120 \mathrm{~km}$ for Eureka, and from 0.23 to $120 \mathrm{~km}$ for Thule), and total and partial columns are then derived by vertically integrating these profiles.

Full error analysis has been performed for both data sets, as described in Rodgers (2000) and Rodgers and Connors (2003), and includes measurement noise error, smoothing error (expressing the limited vertical resolution of the retrieval), and forward model parameter error. Details about the seven tropospheric species error budget can be seen in section 2.6 of Viatte et al. (2014). Time series are obtained from February to October since the FTIR measurements require the sun as the light source. The seasonal cycles of $\mathrm{CO}$, $\mathrm{HCN}, \mathrm{C}_{2} \mathrm{H}_{6}, \mathrm{C}_{2} \mathrm{H}_{2}, \mathrm{CH}_{3} \mathrm{OH}, \mathrm{HCOOH}$, and $\mathrm{H}_{2} \mathrm{CO}$ are representative of their differing transport, emissions, lifetimes, and oxidation rates, and have been discussed in detail in $\mathrm{Vi}$ atte et al. (2014) with reference to the Eureka data set.

The $\mathrm{CO}, \mathrm{HCN}$, and $\mathrm{C}_{2} \mathrm{H}_{6}$ total columns measured at $\mathrm{Eu}-$ reka and Thule from 2008 to 2012 are shown in the left and right panels, respectively, of Fig. 2. These species are considered to be biomass burning tracers, given their long lifetimes in the atmosphere of 52 days (Daniel and Solomon, 1998), 5 months (Li et al., 2003), and 80 days (Xiao et al., 2008) for $\mathrm{CO}, \mathrm{HCN}$, and $\mathrm{C}_{2} \mathrm{H}_{6}$, respectively. They exhibit strong 
seasonal cycles, reflecting the importance of chemistry and transport processes in their Arctic budget. In addition to these cycles, simultaneous enhancements of the $\mathrm{CO}, \mathrm{HCN}$, and $\mathrm{C}_{2} \mathrm{H}_{6}$ total columns can be seen in the day-to-day variabilities, in both Eureka and Thule observations, such as in April and July 2008 (red circles, Fig. 2), and in August 2010 (green squares, Fig. 2). Enhancements of $\mathrm{CO}, \mathrm{HCN}$, and $\mathrm{C}_{2} \mathrm{H}_{6}$ total columns observed at Thule in June-July 2012 (olive triangles, Fig. 2) are not seen in the Eureka data set because there were no FTIR measurements at Eureka during this period. Some of these enhancements have already been attributed to biomass burning plumes transported to the Arctic. This has been done with aircraft measurements for the April 2008 (Warneke et al., 2009) and July 2008 events (Simpson et al., 2011) during the Arctic Research of the Composition of the Troposphere from Aircrafts and Satellites (ARCTAS) campaigns (Jacob et al., 2010; Hornbrook et al., 2011), and with ground-based FTIR measurements for the extreme August 2010 event (Viatte et al., 2013), as well as with the combination of numerous measurement platforms for the July 2011 event, during the Quantifying the impact of BOReal forest fires on Tropospheric oxidants over the Atlantic using Aircraft and Satellites (BORTAS) experiment (Palmer et al., 2013).

Figure 3 shows time series of $\mathrm{C}_{2} \mathrm{H}_{2}, \mathrm{CH}_{3} \mathrm{OH}, \mathrm{HCOOH}$, and $\mathrm{H}_{2} \mathrm{CO}$ total columns measured at Eureka (left panels) and Thule (right panels) from 2008 to 2012. These species have different lifetimes in the atmosphere, ranging from 2 weeks for $\mathrm{C}_{2} \mathrm{H}_{2}$ (Xiao et al., 2007) to less than 2 days for $\mathrm{H}_{2} \mathrm{CO}$ (Coheur et al., 2007). Because of their possible chemical destruction during long-range transport to the Arctic, enhancements due to fire events are less significant than for the three main biomass burning tracers (Fig. 2), but are still present in the time series, as shown in August 2010 for Eureka (green squares, Fig. 3) and in August 2008 for Thule (red circles, Fig. 3). These species have also been measured by Atmospheric Chemistry Experiment-Fourier Transform Spectrometer (ACE-FTS, Tereszchuk et al., 2013) and Infrared Atmospheric Sounding Interferometer (IASI, Coheur et al., 2009) as well as aircraft measurements (Parrington et al., 2013; O'Shea et al., 2013) in boreal forest biomass burning plumes several days after their source emissions. Indeed, a recent study suggests that the physical age of one boreal plume in July 2011 is 1 to 5 days older than the photochemical age because of the presence of the pyrogenic aerosols that slow down the plume photochemistry for several days after the emission (Finch et al., 2014).

For various reasons, the number of days of observations out of the approximate 8-month sunlit portion of the year at these remote Arctic sites will vary year to year from as few as 15 to as many as 110 . Often, days will have multiple observations. For the 5-year period (2008-2012), the average number of measurements per gas shown in Fig. 3 is 2149 for Eureka and 868 for Thule. Despite the difference in the number of FTIR measurements throughout the years between
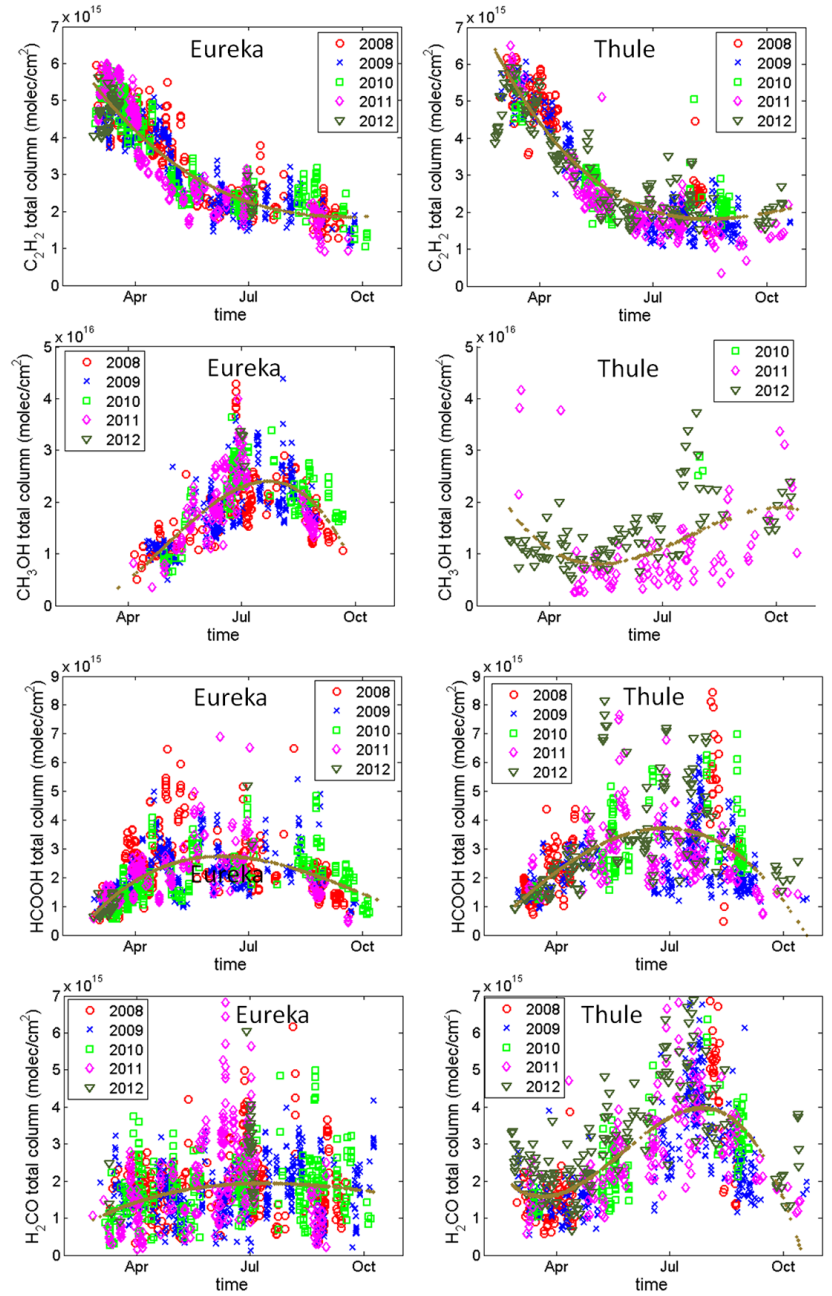

Figure 3. Time series of $\mathrm{C}_{2} \mathrm{H}_{2}, \mathrm{CH}_{3} \mathrm{OH}, \mathrm{HCOOH}$ and $\mathrm{H}_{2} \mathrm{CO}$ total columns measured at Eureka (left panels) and Thule (right panels) from 2008 to 2012. The brown lines represent the polynomial fits to the data.

the Eureka and Thule data sets, the time series of the seven tropospheric species recorded at both stations exhibit similar seasonal cycles in terms of absolute values and temporal variabilities. We can exploit the accuracy of these FTIR retrievals, and the robustness of the multi-year observations, in the quantification of Arctic tropospheric composition and its variability. Super-imposed onto these seasonal cycles, the time series reveal short-term enhancements due to fire events that highlight the importance of the biomass burning longrange transport in the Arctic budget of NMHCs, which can affect air quality and climate in this region.

\subsection{MOZART-4 description}

MOZART-4 (Model for OZone And Related chemical Tracers, version 4), is a chemical transport model (CTM) developed jointly by the (US) National Center for Atmospheric 
Research (NCAR), the Geophysical Fluid Dynamics Laboratory (GFDL), and the Max Planck Institute for Meteorology (MPI-Met) to simulate atmospheric chemical and transport processes. To assess the ability of MOZART-4 to reproduce the different seasonal cycles of the seven tropospheric species, as well as the day-to-day variabilities due to fire signatures, we used daily mean outputs for all of 2008 and a temporal resolution of $6 \mathrm{~h}$ within four time periods between 2008 and 2012 (Emmons et al., 2010) for comparison with the FTIR data sets. Those periods are (1) March to August 2008 to assess the model's seasonal cycles, (2) August to October 2010 to evaluate biomass burning emissions of the model for the most extreme fire event, as well as (3) May to July 2011 and (4) June to July 2012 to focus the analyses on other fire events during summer periods.

For that specific model run, a comprehensive tropospheric chemistry, including 100 species, 160 kinetic, and 40 photolysis reactions, has been used. The simulations are driven by offline meteorological data from the Goddard Earth Observing System Model, version 5 (GEOS-5) and the Modern Era Retrospective analysis for Research and Applications (MERRA) at $0.5^{\circ} \times 0.6^{\circ}$ and $1.9^{\circ} \times 2.5^{\circ}$ resolutions with 56 vertical levels. Emissions are taken from the anthropogenic inventory created for the ARCTAS campaign by David Streets (Argonne National Lab, http: //bio.cgrer.uiowa.edu/arctas/emission.html), which is based on several inventories, including the INTEX-B Asia inventory, the US Environmental Protection Agency (EPA) National Emission Inventory (NEI), the European Monitoring and Evaluation Programme (EMEP) inventory, as well as the Emissions Database for Global Atmospheric Research (EDGAR). For biomass burning emissions, we use the Fire INventory from NCAR (FINN, Wiedinmyer et al., 2011). FINN is based on MODIS thermal anomalies and is available daily (https://www2.acd.ucar.edu/modeling/ finn-fire-inventory-ncar); thus, MOZART-4 simulations do use daily fire emissions. Finally, biogenic emissions are calculated online for isoprene and terpenes, and offline for methanol, from the Model of Emissions of Gases and Aerosols from Nature (MEGAN) inventory (Guenther et al., 2012). At the time the simulations were performed, the significance of biogenic emissions of formic acid was not appreciated, and so were not included. In total, the model has a $\mathrm{HCOOH}$ emission of $3.7 \mathrm{Tg} \mathrm{yr}^{-1}$, for which $1.1 \mathrm{Tg} \mathrm{yr}^{-1}$ are for anthropogenic sources and $3.3 \mathrm{Tg} \mathrm{yr}^{-1}$ for biomass burning. The estimate of biogenic $\mathrm{HCOOH}$ emissions in MEGAN-v2.1 is $3.7 \mathrm{Tg} \mathrm{yr}^{-1}$ (Guenther et al., 2012), so inclusion of them would double the current MOZART-4 emissions.

\section{Methods and results}

\subsection{Detection of biomass burning events with FTIR observations in the Arctic}

We identify fire events in the FTIR time series by selecting all days that have simultaneous enhancements of the three main biomass burning tracers $\left(\mathrm{CO}, \mathrm{HCN}\right.$, and $\left.\mathrm{C}_{2} \mathrm{H}_{6}\right)$. All measurements that lie beyond 3 standard deviations of the monthly mean total columns are considered as biomass burning indicators. This methodology was used in Viatte et al. (2013) and relies on the assumption that a smoke plume detected in the high Arctic has come from a relatively large fire and would have large emissions for several consecutive days.

With this methodology, ten biomass burning events have been identified as reaching Eureka (Table 1), and eight for Thule (Table 2), from 2008 to 2012. At least five fire events reached both sites almost simultaneously in March 2008, July-August 2008, July-August 2010, June-July 2011, and July 2012.

The number of events detected in the high Arctic appears correlated with the boreal forest temperature (Barrett et al., 2013). In summer 2009, only one event in June 2009 was detected over Eureka (Table 1). Low temperatures over the boreal forest (http://earthobservatory.nasa.gov/GlobalMaps/ view.php?d1=MOD14A1_M_FIRE) are consistent with a smaller number of fire events detected at our sites. A recent study of FINN also confirms the smaller number of boreal fires in 2009 (Wiedinmyer et al., 2011, their Table 7).

In order to match the biomass burning candidate events identified in the time series with actual plumes, it is necessary to find the source fires and show that the plumes generated there are capable of travelling to the Arctic stations where they were observed. This is done by using various independent data sets.

1. The Air Resources Laboratory (ARL, http://ready. arl.noaa.gov/hysplit-bin/) Hybrid Single Particle Lagrangian Integrated Trajectory (HYSPLIT) model, which generates mean-wind back-trajectories for air parcels at designated elevations using Global Data Assimilation System (GDAS) meteorological fields (https: //ready.arl.noaa.gov/gdas1.php).

2. The source region information in the form of "footprints", from a time-reversed Lagrangian particle dispersion model, the Stochastic Time-Inverted Lagrangian Transport (STILT, Lin et al., 2003; Gerbig et al., 2003) model, also driven by GDAS meteorological fields. Trajectories were initialized at $0,6,12$, and 18:00 UTC on 23 above-ground-height levels (ranging from 0.2 to $14.5 \mathrm{~km}$ ). Each trajectory used 500 particles. Footprints from the different levels were combined as a weighted mean to create a single footprint that is representative of a column measurement. Weights were derived as the product of the pressure at the receptor 
Table 1. Fire events detected over Eureka with the date, days of measurements, vegetation type burned, fire source location, and travel time to the day of peak enhancement (represented in bold in the third column) used to calculate emission ratios.

\begin{tabular}{|c|c|c|c|c|c|}
\hline \multirow{2}{*}{ Year } & \multirow{2}{*}{ Month } & \multirow{2}{*}{$\begin{array}{l}\text { Days of } \\
\text { measurement }\end{array}$} & \multicolumn{2}{|c|}{ Fire source } & \multirow{2}{*}{$\begin{array}{l}\text { Travel time } \\
\text { used to } \\
\text { calculate ER }\end{array}$} \\
\hline & & & Vegetation type & Location & \\
\hline 2008 & Mar & $\begin{array}{l}20,21,23,24, \mathbf{2 5}, 27 \\
28,29,30,31\end{array}$ & Boreal & Russia & 7 days \\
\hline 2008 & Apr & $\mathbf{1 2}, 14,15,16,17,19$ & $\begin{array}{l}\text { Temperate coniferous } \\
\text { and grassland }\end{array}$ & Central USA & 5 days \\
\hline 2008 & Jul & $\mathbf{1 0}, 12,21,22,23,29$ & Boreal & Russia & 5 days \\
\hline 2009 & Jun & $2,3, \mathbf{5}, 6,8,9,10$ & Boreal & Russia & 6 days \\
\hline 2010 & May & $\mathbf{1 4}, 16,17,21,22$ & $\begin{array}{l}\text { Temperate coniferous } \\
\text { and grassland }\end{array}$ & Central USA & 7 days \\
\hline 2010 & Jul & $3,5,6,9$ & Boreal & $\begin{array}{l}\text { Central Canada } \\
\text { and Alaska }\end{array}$ & 6 days \\
\hline 2010 & Aug & $\begin{array}{l}9,10, \mathbf{1 2}, 13,14,16 \\
18,19,20,22, \mathbf{2 3}, 24 \\
25,28,29\end{array}$ & Boreal & $\begin{array}{l}\text { Fire in Russia in } \\
\text { Moscow area }\end{array}$ & 9 days \\
\hline 2011 & Jun & $6,7,8,9,10,11,13$ & $\begin{array}{l}\text { Boreal and temperate } \\
\text { coniferous and } \\
\text { grassland }\end{array}$ & $\begin{array}{l}\text { Central USA, } \\
\text { Canada }\end{array}$ & 8 days \\
\hline 2011 & Jun/Jul & $\begin{array}{l}27, \mathbf{2 8}, 29,30,1,2, \\
4,5\end{array}$ & Boreal & Canada & 6 days \\
\hline 2012 & Jul & $\mathbf{1}, 2,3,4$ & $\begin{array}{l}\text { Boreal and temperate } \\
\text { coniferous and } \\
\text { grassland }\end{array}$ & $\begin{array}{l}\text { Canada, } \\
\text { central USA }\end{array}$ & 5 days \\
\hline
\end{tabular}

Table 2. Same as Table 1 but for Thule.

\begin{tabular}{|c|c|c|c|c|c|}
\hline \multirow[t]{2}{*}{ Year } & \multirow[t]{2}{*}{ Month } & \multirow{2}{*}{$\begin{array}{l}\text { Days of } \\
\text { measurement }\end{array}$} & \multicolumn{2}{|c|}{ Fire source } & \multirow{2}{*}{$\begin{array}{l}\text { Travel time } \\
\text { used to } \\
\text { calculate ER }\end{array}$} \\
\hline & & & Vegetation type & Location & \\
\hline 2008 & Mar & $\begin{array}{l}\mathbf{2 4}, 25,26,27,29 \\
30,31\end{array}$ & Boreal & Russia & 7 days \\
\hline 2008 & Aug & $2,4,5,6,7,9$ & Boreal & Central Canada & 5 days \\
\hline 2010 & Jul & 30, 31,3 & Boreal & Canada & 5 days \\
\hline 2010 & Aug & $\begin{array}{l}23, \mathbf{2 4}, 25,26,27 \\
28,29,2\end{array}$ & Boreal & $\begin{array}{l}\text { Fire in Russia in } \\
\text { Moscow area }\end{array}$ & 9 days \\
\hline 2011 & Jun & $\begin{array}{l}21,22,25,26,27 \\
\mathbf{2 8}, 29\end{array}$ & Boreal & Canada & 6 days \\
\hline 2011 & Jul & $20,21,23, \mathbf{2 4}, 26,27$ & Boreal & Canada & 6 days \\
\hline 2012 & Apr/May & $\begin{array}{l}27,28,29, \mathbf{8}, 9,10 \\
11,12,13,14\end{array}$ & $\begin{array}{l}\text { Boreal, } \\
\text { temperate } \\
\text { coniferous and } \\
\text { grassland }\end{array}$ & Russia & 7 days \\
\hline 2012 & Jul & $\begin{array}{l}\mathbf{1 5}, 16,18,19,20 \\
22,29,30,31,1\end{array}$ & Boreal & $\begin{array}{l}\text { Canada, } \\
\text { central USA }\end{array}$ & 5 days \\
\hline
\end{tabular}




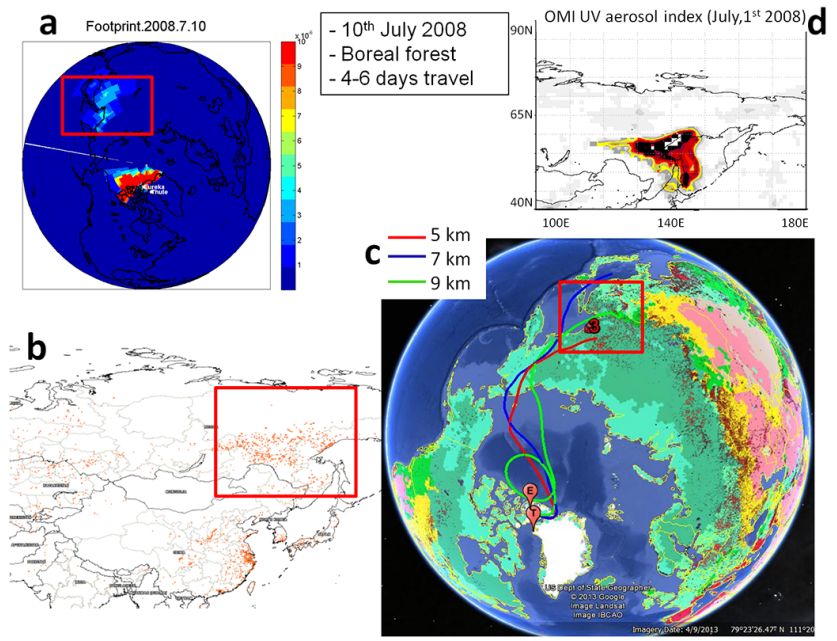

Figure 4. Example of attribution of fire source region and transport time for event number 3, detected at Eureka on 10 July 2008. (a) STILT footprints for that day, (b) MODIS fire hotspots, (c) HYSPLIT back-trajectories ending that day, and (d) OMI UV aerosol index for that day.

multiplied by the instrument kernel density (which was linearly interpolated to the receptor height). The trajectories were run 30 days back in time.

3. The Moderate Resolution Imaging Spectroradiometer (MODIS, http://lance-modis.eosdis.nasa.gov/cgi-bin/ imagery/firemaps.cgi), which captures global fire maps.

4. Satellite images from Ozone Monitoring Instrument (OMI, http://gdata1.sci.gsfc.nasa.gov/daac-bin/G3/gui. cgi?instance_id=omi), which measures the UV aerosol index.

In addition, we use AERONET aerosol optical depth (AOD) data measured at Eureka (O'Neill et al., 2008; Saha et al., 2010; http://aeronet.gsfc.nasa.gov/), when available, to detect simultaneous increases in fine-mode AOD and trace gas total columns, which is an additional fire event indicator. If these data all agree on a common origin for a plume, and the back-trajectories intersect that region during the same time, then the source of a biomass burning event has been successfully detected. Consistent results from these multiple data sets provide confidence in the attribution of trace gas enhancements to specific fire events.

Figure 4 shows an example of the source attribution and the travel duration of a plume that reached Eureka on 10 July 2008. We first note a simultaneous enhancement of the three main biomass burning tracer concentrations detected on 10 July 2008 at Eureka (see Fig. 5). As a priori information, STILT footprints are generated to show the source region influencing the atmospheric measurement at Eureka, which for that day is located in eastern Russia (light blue region inside the red box, Fig. 4a). Then, the FIRMS (Fire Information
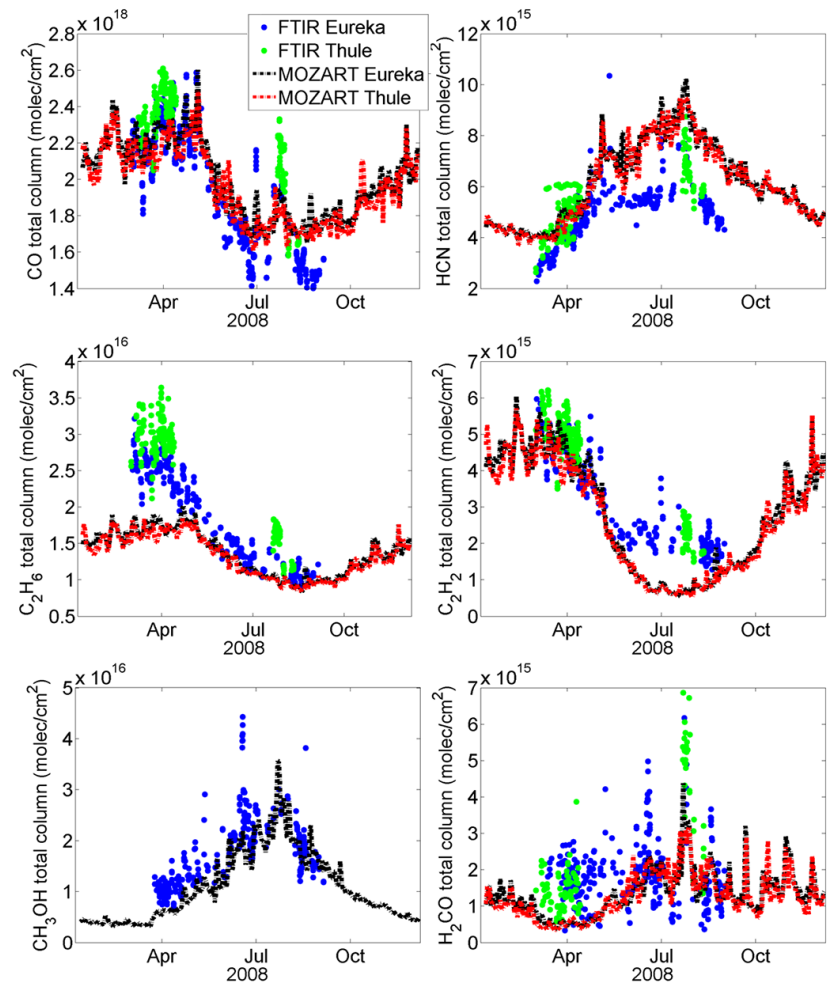

Figure 5. Time series of $\mathrm{CO}, \mathrm{HCN}, \mathrm{C}_{2} \mathrm{H}_{6}, \mathrm{C}_{2} \mathrm{H}_{2}, \mathrm{CH}_{3} \mathrm{OH}$, and $\mathrm{H}_{2} \mathrm{CO}$ total columns measured by the FTIRs at Eureka (blue) and Thule (green) and calculated by MOZART-4 at Eureka (black) and Thule (red) for 2008 .

for Resource Management System, which provides MODIS hotspot data) map is used to verify that a significant fire event occurs in that specific region within a 10 day period (red dots in Fig. 4b). To assess the travel duration of that plume from the fire region to Eureka, an ensemble of HYSPLIT backtrajectories is generated, for several travel times, end times of the calculated trajectories, and air-parcel altitudes; e.g., for each biomass burning event detected at a specific time, we ran ten HYSPLIT back-trajectories for different altitudes ranging from 3 to $12 \mathrm{~km}$, and modified the end time of these back-trajectories within $2 \mathrm{~h}$ of the observed enhancements. In Fig. 4c, air masses ending at Eureka at 5, 7, and $9 \mathrm{~km}$ (red, blue, and green lines, respectively) on 10 July come from the fire region (red box). And finally, the OMI aerosol index map is used to confirm the presence of a significant fire event in that region, as shown in Fig. 4d (colored area within the red box). A similar example of a fire source region and a travel time attribution can be seen in Viatte et al. (2013, Fig. 2) for the August 2010 event.

Using this methodology, four fire plumes were attributed to forest fires in Asia travelling for 7 to 9 days, and six from North America travelling between 5 and 8 days, for Eureka (Table 1). For Thule, three biomass burning plumes come 
from Russia after 7 to 9 days of travel and five are from North America, travelling between 5 and 6 days (Table 2).

In addition, because fire emission composition depends upon, among other parameters, the type of biomass burned (Andreae and Merlet, 2001; Akagi et al., 2011), we assigned the vegetation type burned (boreal, temperate coniferous and grassland; Olson et al., 2001) for the different fire events based on the fire source region. This ensured the appropriate selection of the emission factor (EF) of $\mathrm{CO}$ needed to calculate the emission factors of the other species from the FTIR measurements of emission ratios (Sect. 3.2.2).

\subsection{Evaluation of MOZART-4 in the Arctic}

To assess the capacity of a model to estimate columns and variabilities of tropospheric species in the high Arctic, MOZART-4 was compared to the FTIR data sets. First, the general agreement between MOZART-4 and the measurements from 2008 to 2012 is discussed. Then, we focus on 2008 to analyze the model's ability to reproduce the different seasonal cycles of the seven target species in the troposphere. Finally, we focus on the most extreme fire event detected in our measurements in August-October 2010, to discuss biomass burning emissions used in the model.

\subsubsection{General comparisons between MOZART-4 and the FTIR data sets}

For comparisons with the FTIR data sets, all MOZART-4 data within the closest grid box to both measurement sites, and within $3 \mathrm{~h}$ of each FTIR measurement, are selected. The FTIR and the MOZART-4 trace gas profiles are estimated over different altitude ranges, and with different vertical resolutions. For each molecule, the MOZART-4 profiles are combined with FTIR a priori profiles between $1.9 \mathrm{hPa}(\sim 31 \mathrm{~km})$ and $120 \mathrm{~km}$. After extrapolating these model profiles onto the FTIR pressure grid, the model profiles are smoothed by convolution with the FTIR averaging kernels functions (corresponding to those specific measurements) following the equation (Rodgers and Connors, 2003)

$x_{\mathrm{s}}=\mathbf{A}\left(x-x_{\mathrm{a}}\right)+x_{\mathrm{a}}$,

where $x_{\mathrm{s}}$ is the smoothed MOZART-4 profile, $\mathbf{A}$ is the FTIR averaging kernel matrix and $x_{\mathrm{a}}$ is the FTIR a priori profile. Then, total and tropospheric partial columns (between 0 and $10.25 \mathrm{~km}$ ) are recalculated from the smoothed model profiles. Typical FTIR averaging kernels of the seven tropospheric can be seen in Viatte et al. (2014).

The FTIR retrievals have different vertical sensitivities for each species, characterized by the degrees of freedom for signal (DOFS), ranging on average over 4454 and 1747 measurements from 2.6 to 0.9 for $\mathrm{CO}$ and $\mathrm{H}_{2} \mathrm{CO}$ at Eureka, respectively. For comparisons with the model, total or partial columns may be considered, given the DOFS for that species. For $\mathrm{CO}, \mathrm{HCN}$, and $\mathrm{C}_{2} \mathrm{H}_{6}$, DOFS can be used to separate tropospheric columns from stratospheric columns; therefore, tropospheric partial columns are considered in the comparison with the MOZART-4 data. For the others $\left(\mathrm{C}_{2} \mathrm{H}_{2}\right.$, $\mathrm{CH}_{3} \mathrm{OH}, \mathrm{HCOOH}$, and $\mathrm{H}_{2} \mathrm{CO}$ ), the average DOFS are on order unity; therefore, only total columns are considered. However, these FTIR total columns that are the integrated abundance from the surface to $120 \mathrm{~km}$ are representative of the partial columns $(0-30 \mathrm{~km})$ because the FTIR retrievals of these troposphere species have almost no sensitivity above $30 \mathrm{~km}$, and the tropospheric columns represent more than $90 \%$ of the total columns (Viatte et al., 2014).

The results of comparing the MOZART-4 model and FTIR measurements over selected periods from 2008 to 2012 are shown in Tables 3 and 4, for Eureka and Thule, respectively. $N$ is the number of measurements included in the comparison with MOZART-4. The coefficient of linear correlation $(r)$ ranges from 0.35 to 0.93 , where only two are less than 0.5 and the mean is 0.73 . This shows strong correlations between the model and the measurements despite the larger size of the MOZART- 4 box $\left(1.9^{\circ} \times 2.5^{\circ}\right)$ compared to our column measurements. Excellent correlations are found for $\mathrm{CO}, \mathrm{C}_{2} \mathrm{H}_{6}$, and $\mathrm{C}_{2} \mathrm{H}_{2}$, for which $r>0.74$ at both sites, confirming that the model explains at least $54 \%$ of the atmospheric variability of these species in the Arctic. For $\mathrm{HCN}$, the correlation is better at Eureka $(r=0.92)$ than at Thule $(r=0.55)$; however, the relative differences between the model and the measurements are small $(6.7 \pm 19.3 \%$ for Eureka and $2.2 \pm 19.5 \%$ for Thule), highlighting the very good agreements between these data sets. Also, strong correlations are found for $\mathrm{CH}_{3} \mathrm{OH}(r=0.77$ for Eureka and 0.62 for Thule). For $\mathrm{HCOOH}$ and $\mathrm{H}_{2} \mathrm{CO}$, the correlations of 0.60 and 0.50 , and 0.35 and 0.75 , for Eureka and Thule, respectively, confirm the difficulty in modeling the concentrations of these short-lived species in the high Arctic, and highlight the relatively poor understanding of the sources and sinks of these two molecules.

The mean relative differences ((model-FTIR)/model) between MOZART-4 and $\mathrm{CO}$ and $\mathrm{HCN}$ partial columns are $-2.9 \pm 7.5 \%$ and $6.7 \pm 19.3 \%$ for Eureka, and $-2.5 \pm 11.4 \%$ and $2.2 \pm 19.4 \%$ for Thule, respectively. The 1-sigma standard deviations are larger than the means, confirming the agreement between the model data and the FTIR observations. For $\mathrm{C}_{2} \mathrm{H}_{6}$ partial columns, the mean relative differences of $-50.3 \pm 22.7 \%$ and $-54.1 \pm 29.7 \%$ for Eureka and Thule, respectively, are higher than the standard deviations. We infer that there is a significant underestimation of the $\mathrm{C}_{2} \mathrm{H}_{6}$ concentrations calculated by the model compared to the FTIR measurements. Our results confirm the underestimation of the model already highlighted with aircraft measurements during the ARCTAS campaign (Tilmes et al., 2011; Emmons et al., 2014). The $\mathrm{CH}_{3} \mathrm{OH}$ mean relative differences of $-23.3 \pm 23.4 \%$ and $1.9 \pm 40.8 \%$ for Eureka and Thule, respectively, show good agreement between MOZART-4 and the $\mathrm{CH}_{3} \mathrm{OH}$ FTIR total columns, especially when considering the error bars of the measurements 
Table 3. Results of the 2008-2012 comparisons between MOZART-4 and the FTIR columns measured at Eureka for the seven species listed in the first column. The comparisons are made for the tropospheric columns (0.6-10.25 km) for $\mathrm{CO}, \mathrm{HCN}_{\text {and }} \mathrm{C}_{2} \mathrm{H}_{6}$ and for the total columns (for the other gases). $N$ is the number of points included in the comparisons and $r$ is the coefficient of linear correlation. The relative differences (in percentage) are calculated as (model-FTIR)/model, and SD is the 1-sigma standard deviation around the mean difference. The last four columns are the slopes of the linear regression lines between MOZART-4 and FTIR along with their errors, the error bars in the FTIR total columns (in percentage), and the atmospheric lifetimes of the target species.

\begin{tabular}{|c|c|c|c|c|c|c|c|c|c|}
\hline Gas & Columns & $N$ & $r$ & $\begin{array}{r}\text { Relative } \\
\text { difference } \\
(\%)(\text { model- } \\
\text { FTIR)/model }\end{array}$ & $\mathrm{SD}(\%)$ & $\begin{array}{c}\text { Slope } \\
\text { (MOZART-4 } \\
\text { vs. FTIR) }\end{array}$ & Error on slope & $\begin{array}{c}\text { Error } \\
\text { bar in } \\
\text { FTIR } \\
\text { total } \\
\text { column } \\
(\%)\end{array}$ & $\begin{array}{c}\text { Lifetime } \\
\text { of gas } \\
\text { (days) }\end{array}$ \\
\hline $\mathrm{CO}$ & Tropo & 1001 & 0.879 & 2.888 & 7.532 & 0.667 & 0.011 & 3.1 & 30 \\
\hline $\mathrm{HCN}$ & Tropo & 423 & 0.921 & -6.714 & 19.320 & 0.468 & 0.010 & 10.5 & $30-180$ \\
\hline $\mathrm{C}_{2} \mathrm{H}_{6}$ & Tropo & 452 & 0.849 & 50.282 & 22.680 & 0.506 & 0.015 & 14.3 & 45 \\
\hline $\mathrm{C}_{2} \mathrm{H}_{2}$ & Tot & 289 & 0.927 & 137.047 & 329.439 & 1.548 & 0.037 & 22.5 & 15 \\
\hline $\mathrm{CH}_{3} \mathrm{OH}$ & Tot & 315 & 0.769 & 23.296 & 23.434 & 0.586 & 0.028 & 12.3 & $5-10$ \\
\hline $\mathrm{HCOOH}$ & Tot & 270 & 0.605 & 1504.406 & 894.834 & 0.049 & 0.004 & 17 & $3-4$ \\
\hline $\mathrm{H}_{2} \mathrm{CO}$ & Tot & 445 & 0.494 & 82.057 & 141.583 & 0.357 & 0.030 & 27.5 & $<2$ \\
\hline
\end{tabular}

Table 4. Same as Table 3 but for Thule.

\begin{tabular}{|c|c|c|c|c|c|c|c|}
\hline Gas & Columns & $N$ & $r$ & $\begin{array}{r}\text { Relative } \\
\text { difference } \\
(\%)(\text { model- } \\
\text { FTIR)/model }\end{array}$ & $\mathrm{SD}(\%)$ & $\begin{array}{c}\text { Slope } \\
\text { (MOZART-4 } \\
\text { vs. FTIR) }\end{array}$ & $\begin{array}{l}\text { Error } \\
\text { on } \\
\text { slope }\end{array}$ \\
\hline $\mathrm{CO}$ & Tropo & 145 & 0.736 & -2.48 & 11.37 & 0.529 & 0.041 \\
\hline $\mathrm{HCN}$ & Tropo & 111 & 0.555 & 2.24 & 19.45 & 0.222 & 0.027 \\
\hline $\mathrm{C}_{2} \mathrm{H}_{6}$ & Tropo & 277 & 0.829 & -54.14 & 29.73 & 0.431 & 0.018 \\
\hline $\mathrm{C}_{2} \mathrm{H}_{2}$ & Tot & 139 & 0.908 & -102.14 & 159.10 & 1.145 & 0.045 \\
\hline $\mathrm{CH}_{3} \mathrm{OH}$ & Tot & 118 & 0.620 & 1.93 & 40.79 & 0.390 & 0.046 \\
\hline $\mathrm{HCOOH}$ & Tot & 138 & 0.349 & -1538.70 & 831.12 & 0.010 & 0.002 \\
\hline $\mathrm{H}_{2} \mathrm{CO}$ & Tot & 137 & 0.753 & -152.81 & 129.67 & 0.426 & 0.032 \\
\hline
\end{tabular}

( $12 \%$ ). For $\mathrm{C}_{2} \mathrm{H}_{2}$ and $\mathrm{H}_{2} \mathrm{CO}$ total columns, the agreements are poor, with large standard deviations, and for $\mathrm{HCOOH}$, the model did not include biogenic emissions, explaining the extreme differences.

Finally, the slopes (model vs. FTIR) are all less than 1, except for $\mathrm{C}_{2} \mathrm{H}_{2}$. This indicates that the model underestimates the columns relative to the FTIR data, suggesting that the model underestimates either emissions or transport of the seven tropospheric species in the high Arctic. It could also suggest that the model overestimates their chemical destructions in smoke plumes because of reduced photochemical activity due to aerosol scattering.

\subsubsection{Comparisons of the FTIR and MOZART-4 seasonal cycles in 2008}

The 2008 time series of daily mean $\mathrm{CO}, \mathrm{HCN}, \mathrm{C}_{2} \mathrm{H}_{6}, \mathrm{C}_{2} \mathrm{H}_{2}$, $\mathrm{CH}_{3} \mathrm{OH}$, and $\mathrm{H}_{2} \mathrm{CO}$ total columns measured by the FTIRs at Eureka and Thule (Fig. 5, blue and green dots, respectively), and calculated by MOZART-4 at these two sites (Fig. 5, black and red dashed lines, respectively) are used to compare their seasonal cycles. This year was chosen because the April and July biomass burning events have been studied during the ARCTAS campaign (Jacob et al., 2010, and references therein). There are no $\mathrm{CH}_{3} \mathrm{OH}$ measurements at Thule for 2008 , because the optical filter used to measure this gas was installed in 2010. HCOOH time series are excluded here, because the MOZART-4 runs did not include online biogenic emissions, which have been shown to be a large source of $\mathrm{HCOOH}$ from the boreal forest (Stavrakou et al., 2012), and therefore the model does not capture $\mathrm{HCOOH}$ concentrations and variabilities, by at least an order of magnitude.

In winter, $\mathrm{CO}$ and $\mathrm{C}_{2} \mathrm{H}_{2}$ total columns estimated by MOZART-4 agree very well with the FTIR measurements, suggesting that transport is well represented in the model, since it is the major process controlling the Arctic budget of these long-lived gases in winter. However, for $\mathrm{C}_{2} \mathrm{H}_{6}$, which is also a long-lived tracer, the underestimation of its concentrations by MOZART-4 in winter confirms an underes- 

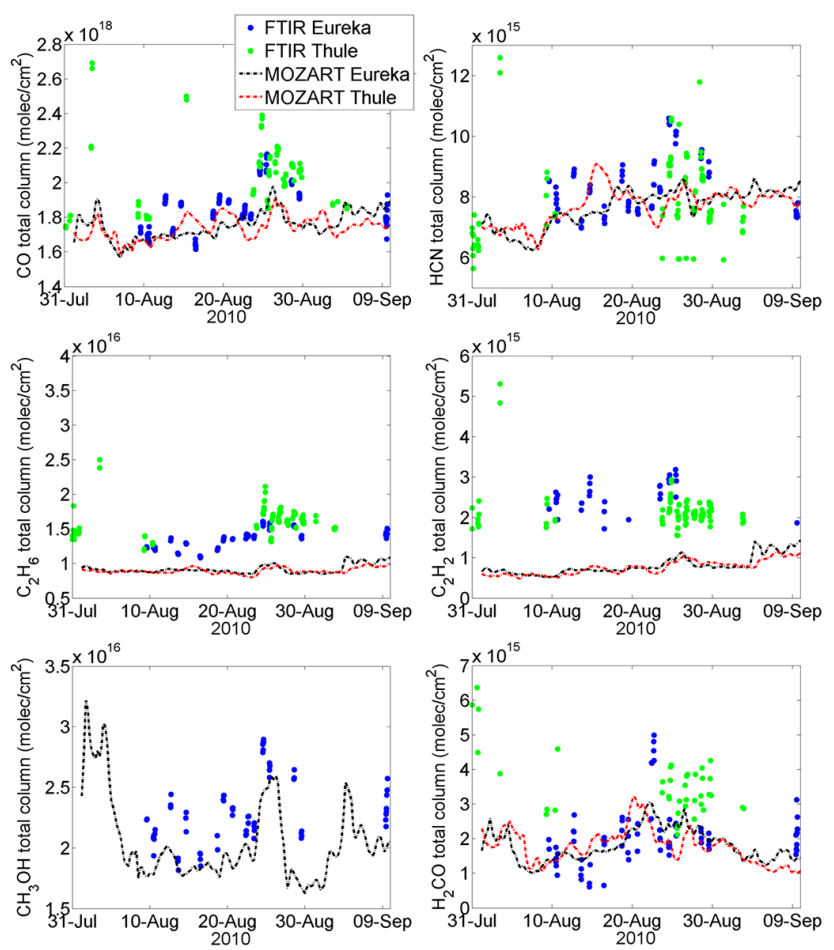

Figure 6. Time series of $\mathrm{CO}, \mathrm{HCN}, \mathrm{C}_{2} \mathrm{H}_{6}, \mathrm{C}_{2} \mathrm{H}_{2}, \mathrm{CH}_{3} \mathrm{OH}$, and $\mathrm{H}_{2} \mathrm{CO}$ total columns measured by the FTIRs at Eureka (blue) and Thule (green) and calculated by MOZART-4 at Eureka (black) and Thule (red) for the August 2010 fire event.

timation in anthropogenic emissions in the model. For HCN, the good agreement in winter also confirms that transport is well reproduced in the model, since $\mathrm{HCN}$ is the longest lived species of those studied here ( 5 months in the troposphere, $\mathrm{Li}$ et al., 2003). In spring and summer, however, the overestimation of the model concentrations suggests that loss processes for $\mathrm{HCN}$ are missing, confirming that its sinks are not well quantified (Zeng et al., 2012). The $\mathrm{CH}_{3} \mathrm{OH}$ seasonal cycle estimated by MOZART-4 exhibits the best agreement with the observational data sets at Eureka.

Focusing on the July 2008 biomass burning event, the $\mathrm{CH}_{3} \mathrm{OH}$ enhanced concentrations are captured well by the model, suggesting that its fire emissions are correct. For CO and $\mathrm{H}_{2} \mathrm{CO}$, enhancements estimated by the model are too low compared to the measurements. This might indicate that their fire emissions are too low in the model. In contrast, the modeled and measured HCN enhancements are similar, so fire emissions of $\mathrm{HCN}$ in the model seem appropriate. For $\mathrm{C}_{2} \mathrm{H}_{6}$ and $\mathrm{C}_{2} \mathrm{H}_{2}$, the modeled enhancements are extremely low compared to the measurements, indicating missing sources.

\subsubsection{Comparisons of MOZART-4 and FTIR during the August 2010 fire events}

To further assess the estimation of fire emissions in the model, we focus on the most extreme event in our data sets in August 2010. Details about the origin and transport of the plume from Russia through the Arctic are described in Viatte et al. (2013). Figure 6 shows the time series of $\mathrm{CO}, \mathrm{HCN}$, $\mathrm{C}_{2} \mathrm{H}_{6}, \mathrm{C}_{2} \mathrm{H}_{2}, \mathrm{CH}_{3} \mathrm{OH}$, and $\mathrm{H}_{2} \mathrm{CO}$ total columns measured by the FTIR at Eureka (blue dots) and Thule (green dots) and calculated by MOZART-4 at Eureka (black dashed line) and Thule (red dashed line) for the August 2010 fire event.

Except for $\mathrm{C}_{2} \mathrm{H}_{6}$ and $\mathrm{C}_{2} \mathrm{H}_{2}$, total columns measured by the FTIR and calculated by the model are generally in agreement during this fire event. In addition, enhancements due to the fire plume recorded at both stations around 23 August are captured in the model. However, the amplitudes of these enhancements in MOZART-4, which reflect fire emissions in the model, seem too low for all the gases, except for $\mathrm{CH}_{3} \mathrm{OH}$ and $\mathrm{H}_{2} \mathrm{CO}$. For $\mathrm{CO}$, fire emissions in MOZART-4 are too low, as seen previously (Sect. 3.2.2). For $\mathrm{C}_{2} \mathrm{H}_{6}$ and $\mathrm{C}_{2} \mathrm{H}_{2}$, concentrations calculated by the model are biased low, indicating missing sources. For $\mathrm{CH}_{3} \mathrm{OH}$, fire emissions estimated in the model seem appropriate.

\subsection{Estimation of emissions from fires with FTIR measurements}

\subsubsection{Correlation between $\mathrm{CO}$ and the other trace gases}

In order to estimate emissions from fires, all fire-affected measurements identified in the biomass burning events reaching the two Arctic sites (Tables 5 and 6) from 2008 to 2012 are used. Concentrations within smoke plumes vary rapidly with time, so emission factors are derived by measuring the emission ratio of the target chemical species relative to a reference species, which is often $\mathrm{CO}_{2}$ or $\mathrm{CO}$ (Hurst et al., 1994). We use CO as the reference because these measurements are most sensitive to plume enhancements. Because the emission ratio is not measured at the source of the fire, the downstream measurements here more accurately yield an "enhancement ratio" (EnhR). These ratios are derived from the regression slopes of a given trace gas total column versus that of $\mathrm{CO}$, for each fire event. Since the spectral acquisitions require the use of optical filters, and spectra are taken sequentially, we selected all CO measurements made within a 20 min interval of the target gas measurement in order to calculate enhancement ratios. Uncertainties in this tracer/tracer enhancement ratio method are small if both tracers have long atmospheric lifetimes relative to plume travel durations between the fire source and the measurements. In addition, errors in transport and plume altitude are also minimized, since all tracers are expected to be mixed and transported in the same air masses. These assumptions constitute the main limitation of this approach (Yokelson et al., 2013).

Figures 7 and 8 show the correlation plots of the total columns of the target species relative to $\mathrm{CO}$, for all fire events (represented by different colors) detected at Eureka and Thule, respectively. For Eureka (and Thule), the en- 

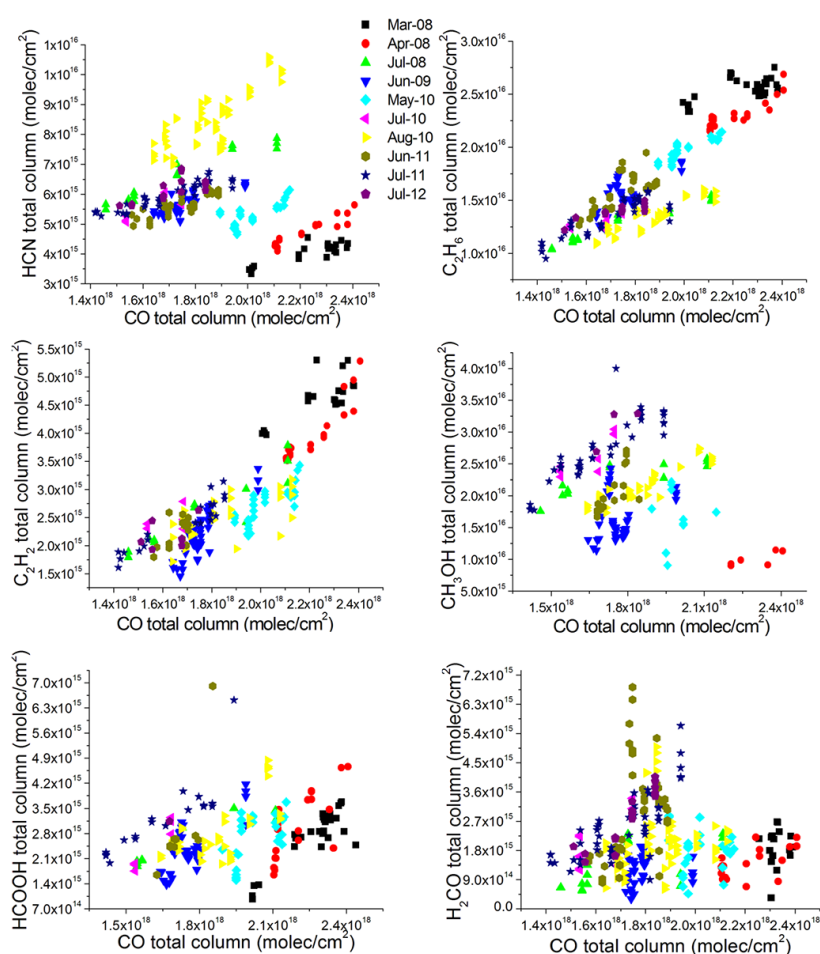

Figure 7. Scatterplots of the total columns of the target species ( $\mathrm{HCN}, \mathrm{C}_{2} \mathrm{H}_{6}, \mathrm{C}_{2} \mathrm{H}_{2}, \mathrm{CH}_{3} \mathrm{OH}, \mathrm{HCOOH}$, and $\mathrm{H}_{2} \mathrm{CO}$ ) relative to $\mathrm{CO}$ for the ten fire events detected at Eureka (2008-2012).

hancement ratios are estimated from each biomass burning event, with 313 (136), 321 (274), 205 (137), 228 (-), 202 (120), and 298 (149) pairs of CO columns with $\mathrm{HCN}, \mathrm{C}_{2} \mathrm{H}_{6}$, $\mathrm{C}_{2} \mathrm{H}_{2}, \mathrm{CH}_{3} \mathrm{OH}, \mathrm{HCOOH}$, and $\mathrm{H}_{2} \mathrm{CO}$ columns, respectively. Given the small number of $\mathrm{CH}_{3} \mathrm{OH}$ FTIR observations at Thule, we did not estimate its enhancement ratio here (see below).

The correlations of $\mathrm{HCN}, \mathrm{CH}_{3} \mathrm{OH}, \mathrm{HCOOH}$, and $\mathrm{H}_{2} \mathrm{CO}$ total columns with $\mathrm{CO}$ using all of the fire data sets (all colors combined, Figs. 7 and 8) are not linear, since these species have different atmospheric lifetimes from $\mathrm{CO}$ (Viatte et al., 2014). In contrast, $\mathrm{CO}, \mathrm{C}_{2} \mathrm{H}_{6}$, and $\mathrm{C}_{2} \mathrm{H}_{2}$ have common sinks and sources, so their columns are expected to be correlated throughout the year. Except for $\mathrm{H}_{2} \mathrm{CO}$, correlations of the fire species with $\mathrm{CO}$ in the individual fire plumes (individual colors, Figs. 7 and 8) exhibit linear patterns. This confirms that the target gases are transported in the same air masses from the emitted fire sources. For $\mathrm{H}_{2} \mathrm{CO}$, the correlations with $\mathrm{CO}$ are not clearly linear inside fire plumes. However, the measured total columns are significantly enhanced (up to $4.5 \times 10^{15}$ molecules $\mathrm{cm}^{-2}$ ) in August 2008 at Thule, in August and July 2010 at Eureka and Thule, respectively, in June 2011 and July 2011 at both sites, as well as in July 2012 at Thule. Given the back-trajectory analyses, these enhanced $\mathrm{H}_{2} \mathrm{CO}$ columns recorded in the high Arctic are cor-
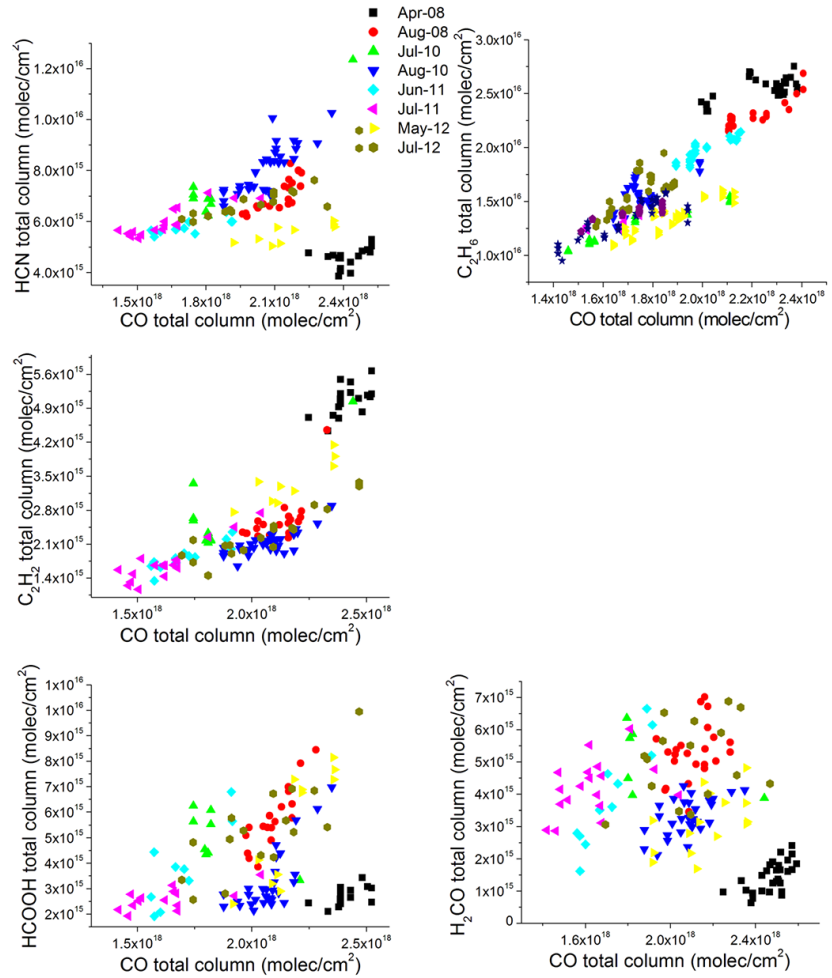

Figure 8. Scatterplots of the total columns of the target species ( $\mathrm{HCN}, \mathrm{C}_{2} \mathrm{H}_{6}, \mathrm{C}_{2} \mathrm{H}_{2}, \mathrm{HCOOH}$, and $\mathrm{H}_{2} \mathrm{CO}$ ) relative to $\mathrm{CO}$ for the eight fire events detected at Thule (2008-2012).

related with extreme fire events in the boreal forest during summer.

For each event, the slopes of the regression lines are taken as the enhancement ratios of the species emitted by fires. The correlations are obtained by linear regression using the method of York et al. (2004), which takes into account uncertainties in both ordinate and abscissa variables. The total uncertainty for the regression slopes is calculated by quadrature addition of the fit uncertainties and the measurement uncertainties. Those values are summarized in Tables 5 and 6 for Eureka and Thule, respectively. $N$ is the number of pairs (between the target species vs. CO) used to estimate the enhancement ratios, $r$ is the correlation coefficient of the linear regression, and EnhR is the enhancement ratio given by the slope of the regression line for each fire event. To assess changes due to photochemistry during plume aging (Akagi et al., 2012), the enhancement ratio corrected by the travel time of the plume (ER) has been included in Tables 5 and 6 . If less than six pairs are measured in a fire plume, the enhancement ratios are not estimated from this event, i.e., $\mathrm{C}_{2} \mathrm{H}_{2}$ measurements at Eureka in July 2010. No error weighting was performed according to the number of points.

The correlation coefficients between $\mathrm{HCN}$ and $\mathrm{CO}$ total columns are on average 0.84 and 0.79 for the Eureka and Thule data sets, respectively (last columns in Tables 5 and 
Table 5. Correlation between each trace gas and CO inside the smoke plumes detected over Eureka. $N$ is the number of points, $r$ is the coefficient of linear correlation and EnhR is the enhancement ratio, which is the slope derived from the correlation. For all gases except $\mathrm{H}_{2} \mathrm{CO}$, ER represents the corrected enhancement ratios from travel time calculated only if the linear correlation coefficient $(r>0.6)$ and the number of points $(N>=6) .{ }^{*}$ Values excluded from the mean calculations.

\begin{tabular}{|c|c|c|c|c|c|c|c|c|c|c|c|c|}
\hline Gas & $\begin{array}{l}\text { Year } \\
\text { Month }\end{array}$ & $\begin{array}{l}2008 \\
\text { Mar }\end{array}$ & $\begin{array}{c}2008 \\
\text { Apr }\end{array}$ & $\begin{array}{c}2008 \\
\text { Jul }\end{array}$ & $\begin{array}{c}2009 \\
\text { Jun }\end{array}$ & $\begin{array}{l}2010 \\
\text { May }\end{array}$ & $\begin{array}{c}2010 \\
\text { Jul }\end{array}$ & $\begin{array}{l}2010 \\
\text { Aug }\end{array}$ & $\begin{array}{c}2011 \\
\text { Jun }\end{array}$ & $\begin{array}{c}2011 \\
\text { Jun/Jul }\end{array}$ & $\begin{array}{c}2012 \\
\text { Jul }\end{array}$ & Mean \pm SD \\
\hline \multirow[t]{3}{*}{$\mathrm{HCN}$} & $N$ & 20 & 20 & 16 & 48 & 32 & 12 & 66 & 44 & 38 & 17 & \\
\hline & $\mathrm{EnhR} \times 10^{-3}$ & 2.28 & 3.75 & 3.52 & 3.05 & 2.89 & 3.95 & 6.07 & 2.97 & 2.55 & 2.62 & $3.37 \pm 1.08$ \\
\hline & ER & 2.23 & 3.64 & 3.42 & 3.17 & 3.03 & 3.77 & 5.63 & 2.93 & 2.40 & 3.25 & $3.34 \pm 0.94$ \\
\hline \multirow[t]{3}{*}{$\mathrm{C}_{2} \mathrm{H}_{6}$} & $N$ & 30 & 22 & 16 & 49 & 32 & 12 & 64 & 41 & 38 & 17 & \\
\hline & $E n h R \times 10^{-3}$ & 5.15 & 10.30 & 7.34 & 14.25 & 10.65 & 4.27 & 9.69 & 13.04 & 9.98 & 5.23 & $8.99 \pm 3.40$ \\
\hline & ER & 5.36 & 10.60 & 7.55 & 14.74 & 11.08 & 4.42 & 10.19 & 13.63 & 10.32 & 7.77 & $9.56 \pm 3.19$ \\
\hline \multirow[t]{3}{*}{$\mathrm{C}_{2} \mathrm{H}_{2}$} & $N$ & 20 & 21 & 13 & 48 & 31 & & 30 & 14 & 20 & 8 & \\
\hline & $r$ & 0.76 & 0.93 & 0.92 & 0.87 & 0.78 & & 0.63 & 0.61 & 0.93 & 0.55 & $0.78 \pm 0.15$ \\
\hline & $E n h R \times 10^{-3}$ & 2.36 & 4.16 & 2.24 & 5.71 & 2.93 & & 1.36 & 3.80 & 2.45 & 0.98 & $2.89 \pm 1.47$ \\
\hline $\mathrm{CH}_{3} \mathrm{OH}$ & ER & & 15.70 & 15.71 & & & 37.64 & 28.37 & $114.91^{*}$ & 43.24 & & $28.13 \pm 12.52$ \\
\hline \multirow[t]{4}{*}{$\mathrm{HCOOH}$} & $N$ & 28 & 21 & 10 & 44 & 27 & 6 & 38 & 9 & 19 & & \\
\hline & $r$ & 0.87 & 0.75 & 0.93 & 0.74 & 0.53 & 0.97 & 0.67 & 0.78 & 0.83 & & $0.79 \pm 0.13$ \\
\hline & $E n h R \times 10^{-3}$ & 6.30 & 10.42 & 2.69 & 7.48 & 8.34 & 8.10 & 3.14 & 22.14 & 4.13 & & $8.08 \pm 5.87$ \\
\hline & ER & 11.37 & 17.60 & 11.13 & 13.12 & 14.21 & 5.90 & 40.86 & 8.30 & & & $15.31 \pm 4.03$ \\
\hline \multirow[t]{3}{*}{$\mathrm{H}_{2} \mathrm{CO}$} & $N$ & 16 & 18 & 16 & 38 & 28 & 12 & 64 & 43 & 45 & 18 & \\
\hline & $r$ & 0.08 & 0.58 & 0.64 & 0.15 & -0.09 & 0.51 & 0.16 & 0.42 & 0.74 & 0.9 & $0.41 \pm 0.32$ \\
\hline & $E n h R \times 10^{-3}$ & $159.2^{*}$ & 4.13 & 1.38 & 8.16 & 7.17 & 2.92 & 3.41 & 12.13 & 4.28 & 7.4 & $5.37 \pm 3.86$ \\
\hline
\end{tabular}

6). Good correlations between $\mathrm{C}_{2} \mathrm{H}_{6}$ and $\mathrm{CO}$ total columns $(r=0.81$ on average for both data sets) also confirm that the selected measurements, listed in Tables 1 and 2, were made inside fire plumes. The means of the correlation coefficients between $\mathrm{C}_{2} \mathrm{H}_{2}$ and $\mathrm{CO}$ total columns inside plumes are 0.78 and 0.80, for Eureka and Thule, respectively. For $\mathrm{CH}_{3} \mathrm{OH}$, the average of the coefficients of correlation is 0.65 at Eureka. The $\mathrm{HCOOH}$ total columns are also well correlated with $\mathrm{CO}$ inside the plumes, given the average values of $r$ of 0.79 and 0.58 at Eureka and Thule, respectively. However, the July 2010 event has a negative correlation coefficient between $\mathrm{HCOOH}$ and $\mathrm{CO}$ at Thule, but the small numbers of points ( $N=6$ and 8, for Eureka and Thule, respectively) are too low to draw significant conclusions. The mean correlation coefficients between the $\mathrm{H}_{2} \mathrm{CO}$ and $\mathrm{CO}$ total columns are similar: $r=0.41$ and 0.40 at Eureka and Thule, respectively. Given the short atmospheric lifetime of this molecule and the fact that the measurements are not performed at the source of the fires, $\mathrm{H}_{2} \mathrm{CO}$ could have been destroyed in the atmosphere while being transported through the Arctic. However, the wide ranges of the $r$ values, from 0.08 to 0.90 at Eureka in March 2008 and July 2012, and from 0.34 to 0.93 in August 2008 and June 2011 at Thule, suggest a possible secondary production of $\mathrm{H}_{2} \mathrm{CO}$ in some atmospheric smoke plumes, where $r$ is high. Young and Paton-Walsh (2011) also show that concentrations of $\mathrm{H}_{2} \mathrm{CO}$ within Australian smoke plumes increase during the first day of travel before declining 2 days after they were emitted.

The enhancement ratios are expected to vary with the travel time of the plumes from their source to the measurement site (see the last columns in Tables 1 and 2), especially for short-lived species, because of their faster atmospheric destruction (via photochemistry, oxidation, as well as dry and wet depositions) compared to CO. However, the mean enhancement ratios of the target gases over all fire events are comparable for the two sites. For instance, the Eureka and Thule mean enhancement ratios of $\mathrm{HCN}$, over all biomass burning events, are $0.00334 \pm 0.00094$ (1-sigma standard deviation) and $0.00429 \pm 0.00245$, respectively (last columns in Tables 5 and 6). In addition, the enhancement ratios of $\mathrm{HCN}, \mathrm{C}_{2} \mathrm{H}_{6}$, and $\mathrm{C}_{2} \mathrm{H}_{2}$ estimated from the extreme fire event of August 2010 are very similar: 0.00563 and 0.00650 for $\mathrm{HCN}, 0.01019$ and 0.01235 for $\mathrm{C}_{2} \mathrm{H}_{6}$, and 0.00189 and 0.00191 for $\mathrm{C}_{2} \mathrm{H}_{2}$, for Eureka and Thule, respectively. 
Table 6. Correlation between each trace gas and $\mathrm{CO}$ inside the smoke plumes detected over Thule. $N$ is the number of points, $r$ is the coefficient of linear correlation and EnhR are the enhancement ratios, which are the slopes derived from the correlation. For all gases except $\mathrm{H}_{2} \mathrm{CO}$, ER represents the corrected enhancement ratios from travel time (calculated only if the linear correlation coefficient $(r>0.6)$ ) and the number of points $(N>=6)$.

\begin{tabular}{lcccccccccc}
\hline Gas & $\begin{array}{c}\text { Year } \\
\text { Month }\end{array}$ & $\begin{array}{c}2008 \\
\text { Mar }\end{array}$ & $\begin{array}{c}2008 \\
\text { Aug }\end{array}$ & $\begin{array}{c}2010 \\
\text { Jul }\end{array}$ & $\begin{array}{c}2010 \\
\text { Aug }\end{array}$ & $\begin{array}{c}2011 \\
\text { Jun }\end{array}$ & $\begin{array}{c}2011 \\
\text { Jul }\end{array}$ & $\begin{array}{c}2012 \\
\text { Apr/May }\end{array}$ & $\begin{array}{c}2012 \\
\text { Jul }\end{array}$ & Mean \pm SD \\
\hline $\mathrm{HCN}$ & $N$ & 17 & 20 & 9 & 34 & 12 & 17 & 9 & 18 & \\
& $r$ & 0.42 & 0.79 & 0.96 & 0.79 & 0.8 & 0.87 & 0.8 & 0.85 & $0.79 \pm 0.16$ \\
& EnhR $\times 10^{-3}$ & 4.20 & 6.09 & 8.24 & 7.16 & 1.60 & 3.06 & 1.93 & 2.95 & $4.40 \pm 2.48$ \\
& $\mathrm{ER}$ & & 5.78 & 7.83 & 6.50 & 1.50 & 2.87 & 1.79 & 3.75 & $4.29 \pm 2.45$ \\
\hline $\mathrm{C}_{2} \mathrm{H}_{6}$ & $N$ & 33 & 44 & 16 & 64 & 23 & 35 & 25 & 34 & \\
& $r$ & 0.85 & 0.14 & 0.93 & 0.89 & 0.92 & 0.89 & 0.95 & 0.9 & $0.81 \pm 0.27$ \\
& $\mathrm{EnhR} \times 10^{-3}$ & 17.27 & -0.02 & 17.98 & 11.75 & 10.10 & 6.33 & 11.56 & 6.73 & $10.21 \pm 5.93$ \\
& $\mathrm{ER}$ & 17.96 & & 18.50 & 12.35 & 10.45 & 6.55 & 12.02 & 6.92 & $12.11 \pm 4.76$ \\
\hline $\mathrm{C}_{2} \mathrm{H}_{2}$ & $N$ & 17 & 21 & 9 & 34 & 12 & 17 & 9 & 18 & \\
& $r$ & 0.58 & 0.63 & 0.85 & 0.76 & 0.88 & 0.91 & 0.88 & 0.91 & $0.80 \pm 0.13$ \\
& $\mathrm{Enh} \times 10^{-3}$ & 2.58 & 1.88 & 3.56 & 1.37 & 1.88 & 2.22 & 2.52 & 1.92 & $2.24 \pm 0.66$ \\
& $\mathrm{ER}$ & & 2.33 & 4.42 & 1.91 & 2.41 & 2.84 & 3.33 & 2.38 & $2.80 \pm 0.84$ \\
\hline
\end{tabular}

\begin{tabular}{|c|c|c|c|c|c|c|c|c|c|c|}
\hline $\mathrm{CH}_{3} \mathrm{OH}$ & $\begin{array}{c}N \\
r \\
\text { EnhR } \times 10^{-3}\end{array}$ & & & & & & & & & \\
\hline \multirow[t]{4}{*}{$\mathrm{HCOOH}$} & $N$ & 13 & 19 & 8 & 30 & 9 & 14 & 11 & 16 & \\
\hline & $r$ & 0.55 & 0.87 & -0.71 & 0.76 & 0.84 & 0.65 & 0.88 & 0.77 & $0.58 \pm 0.53$ \\
\hline & $\operatorname{EnhR} \times 10^{-3}$ & 3.80 & 13.78 & -4.47 & 10.77 & 12.12 & 1.57 & 15.93 & 6.58 & $7.51 \pm 6.92$ \\
\hline & ER & & 23.27 & & 20.22 & 21.26 & 2.75 & 28.76 & 11.11 & $17.90 \pm 9.37$ \\
\hline \multirow[t]{3}{*}{$\mathrm{H}_{2} \mathrm{CO}$} & $N$ & 30 & 23 & 6 & 30 & 11 & 18 & 15 & 16 & \\
\hline & $r$ & 0.64 & 0.34 & -0.55 & 0.57 & 0.93 & 0.38 & 0.56 & 0.3 & $0.40 \pm 0.43$ \\
\hline & $\mathrm{EnhR} \times 10^{-3}$ & 6.02 & 3.85 & -1.76 & 3.70 & 11.79 & 2.21 & 3.58 & 2.52 & $3.99 \pm 3.85$ \\
\hline
\end{tabular}

\subsubsection{Calculation of emission ratios (ERs) and emission factors (EFs)}

In models, fire emissions are often specified by using emission ratios relative to a reference species, typically $\mathrm{CO}$, which correspond to measured ratios at the source of the biomass burning event. Those emission ratios are equal to the enhancement ratios corrected for the travel duration of the plume. By considering the different lifetimes of the molecules (Table 3, last column) as well as the plume travel times to reach Eureka and Thule (last columns of Tables 1 and 2), we calculated the decay rates of each species to obtain the percentage of their initial values remaining when they were measured. This allows the measured enhancement ratios to be corrected to the equivalent emission ratios (PatonWalsh et al., 2005; Akagi et al., 2011; Hornbrook et al., 2011). More details regarding this correction are found in Viatte el al. (2013). Since the uncertainty in the correction is small compared to other uncertainties, our equivalent emission ratios can be compared to other emission ratios found in the literature. For comparison with previous studies, our equivalent emission ratios have been converted into equiva- lent emission factors using Andreae and Merlet (2001):

$\mathrm{EF}_{\mathrm{x}}=\mathrm{ER}_{(\mathrm{x} / \mathrm{CO})} \times\left(\mathrm{MW}_{\mathrm{x}} / \mathrm{MW}_{\mathrm{CO}}\right) \times \mathrm{EF}_{\mathrm{CO}}$,

where $\mathrm{EF}_{\mathrm{X}}$ is the emission factor for trace gas $\mathrm{X}$ in $\mathrm{g}$ of gas per $\mathrm{kg}$ of dry biomass burnt; $\mathrm{ER}_{(\mathrm{x} / \mathrm{CO})}$ is the molar emission ratio of trace gas $\mathrm{X}$ with respect to $\mathrm{CO} ; \mathrm{MW}_{\mathrm{x}}$ is the molecular weight of trace gas $\mathrm{X} ; \mathrm{MW}_{\mathrm{CO}}$ is the molecular weight of $\mathrm{CO}$; and $\mathrm{EF}_{\mathrm{CO}}$ is the emission factor of $\mathrm{CO}$.

In this study, values of $\mathrm{EF}_{\mathrm{CO}}$ of $127 \pm 45 \mathrm{~g} \mathrm{~kg}^{-1}$ and $107 \pm 37 \mathrm{~g} \mathrm{~kg}^{-1}$ for dry matter based on Akagi et al. (2011) and Andreae and Merlet (2001), respectively, are taken as the emission factors for $\mathrm{CO}$ for boreal and extratropical forests, since this is the fuel type of the relevant source fires (vegetation type columns in Tables 1 and 2). Uncertainties in the measured EF are calculated by taking into account the large uncertainty in the $\mathrm{CO}$ emission factor (more than $35 \%$ ) and the uncertainty in the mean calculated regression slope (33.6, 54.0, 49.5, 32.2 and $22.8 \%$ for $\mathrm{HCN}, \mathrm{C}_{2} \mathrm{H}_{6}, \mathrm{C}_{2} \mathrm{H}_{2}, \mathrm{CH}_{3} \mathrm{OH}$, and $\mathrm{HCOOH}$ at Eureka, respectively, and 43.5, 33.1, 52.5, and $16.3 \%$ for $\mathrm{HCN}, \mathrm{C}_{2} \mathrm{H}_{6}, \mathrm{C}_{2} \mathrm{H}_{2}$, and $\mathrm{HCOOH}$, respectively, at Thule), as well as the total uncertainties in the retrievals $(3.1,10.5,14.3,22.5,12.3$, and $17.0 \%$ for $\mathrm{CO}, \mathrm{HCN}$, 


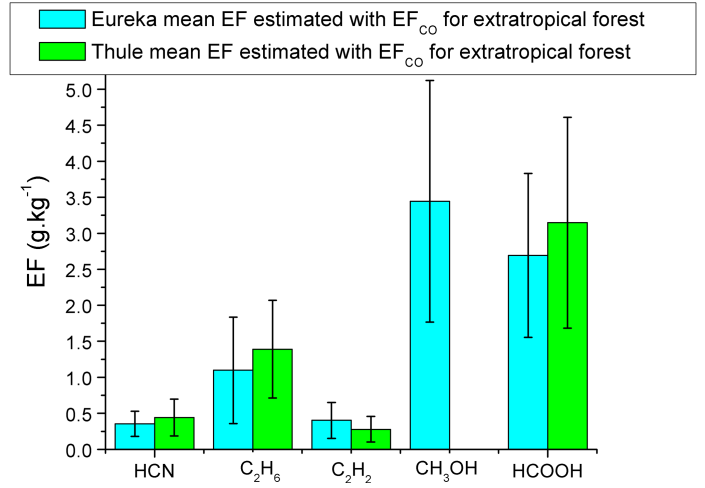

Figure 9. Emission factors calculated from the FTIR measurements performed at Eureka (cyan) and Thule (green), using $\mathrm{EF}_{\mathrm{CO}}$ of Andreae and Merlet (2001) for extratropical forest. Error bars correspond to the uncertainty in the $\mathrm{CO}$ emission factor and the uncertainty in the calculated regression slope, as well as the total uncertainties in the retrievals, all combined in quadrature.

$\mathrm{C}_{2} \mathrm{H}_{2}, \mathrm{C}_{2} \mathrm{H}_{6}, \mathrm{CH}_{3} \mathrm{OH}$, and $\mathrm{HCOOH}$, respectively; Viatte et al., 2014, their Table 3), all combined in quadrature (PatonWalsh et al., 2005). Total uncertainties in EFs are 49.2, 67.3, $61.8,48.7$, and $42.3 \%$ for $\mathrm{HCN}, \mathrm{C}_{2} \mathrm{H}_{6}, \mathrm{C}_{2} \mathrm{H}_{2}, \mathrm{CH}_{3} \mathrm{OH}$, and $\mathrm{HCOOH}$, at Eureka, respectively, and 57.5, 48.7, 63.8, and $46.5 \%$ for $\mathrm{HCN}, \mathrm{C}_{2} \mathrm{H}_{6}, \mathrm{C}_{2} \mathrm{H}_{2}$, and $\mathrm{HCOOH}$, at Thule, respectively. Because the uncertainties in the FTIR $\mathrm{H}_{2} \mathrm{CO}$ retrievals are high $(\sim 27 \%)$ and the transport times of the plumes to the Arctic exceed its atmospheric lifetime (which is less than 2 days), emission ratios of $\mathrm{H}_{2} \mathrm{CO}$ have not been estimated in this study.

Our corrected enhancement ratios (i.e., equivalent emission ratios, "ER" in Tables 5 and 6) have been converted into equivalent emission factors using Eq. (2). Only enhancement ratios calculated from more than six pairs $(N>6)$, and satisfying a coefficient of correlation of more than $0.6(r>0.6)$, are taken into account to estimate emission factors. The means of equivalent emission ratios and emission factors (calculated using $\mathrm{EF}_{\mathrm{CO}}$ for the extratropical forest) estimated from FTIR measurements performed at Eureka and Thule are summarized in Table 7.

Figure 9 shows the emission factors calculated from FTIR measurements performed at Eureka (cyan) and Thule (green), using the same $\mathrm{EF}_{\mathrm{CO}}$ of Andreae and Merlet (2001) for the extratropical forest. All emission factors estimated from both FTIR data sets agree well within combined error bars. The means of the emission factors estimated from the Eureka and Thule FTIR data sets are $0.36 \pm 0.17 \mathrm{~g} \mathrm{~kg}^{-1}$ and $0.44 \pm 0.25 \mathrm{~g} \mathrm{~kg}^{-1}$ for $\mathrm{HCN}, 1.09 \pm 0.74 \mathrm{~g} \mathrm{~kg}^{-1}$ and $1.39 \pm 0.68 \mathrm{~g} \mathrm{~kg}^{-1}$ for $\mathrm{C}_{2} \mathrm{H}_{6}$, $0.40 \pm 0.25 \mathrm{~g} \mathrm{~kg}^{-1}$ and $0.28 \pm 0.18 \mathrm{~g} \mathrm{~kg}^{-1}$ for $\mathrm{C}_{2} \mathrm{H}_{2}$, and $2.69 \pm 1.14 \mathrm{~g} \mathrm{~kg}^{-1}$ and $3.15 \pm 1.46 \mathrm{~g} \mathrm{~kg}^{-1}$ for $\mathrm{HCOOH}$, respectively. For $\mathrm{CH}_{3} \mathrm{OH}$, we estimated a mean emission factor of $3.44 \pm 1.68 \mathrm{~g} \mathrm{~kg}^{-1}$ at Eureka (Table 7). The emission fac-

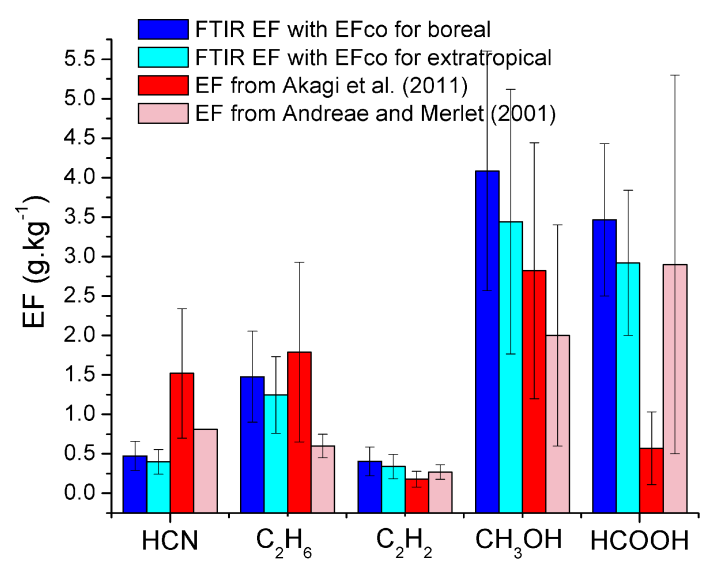

Figure 10. Emission factors for boreal and extratropical $\mathrm{EF}_{\mathrm{CO}}$ calculated from FTIR measurements (blue and cyan), along with the emission factors found in the compilation studies of Akagi et al. (2011) (red) and Andreae and Merlet (2001) (pink).

tors derived from the Thule data set are slightly higher than those for Eureka, except for $\mathrm{C}_{2} \mathrm{H}_{2}$, but these differences are not significant given the error bars. However, the $\mathrm{EF}_{\mathrm{HCOOH}}$ is notably higher at Thule than at Eureka. A possible explanation is that our Thule measurements of $\mathrm{HCOOH}$ from fire events are contaminated by local biogenic emissions.

In order to compare our results with others, emission factors from two compilations of data (Andreae and Merlet, 2001; Akagi et al., 2011) for extratropical and boreal forests have been selected. These studies contain a comprehensive set of emission factors from the burning of numerous vegetation types derived from various measurement platforms. Figure 10 shows the emission factors calculated from the FTIR measurements (in blue and cyan), along with the emission factors found in the compilation studies of Akagi et al. (2011) (red) and Andreae and Merlet (2001) (pink). The blue color corresponds to the emission factors calculated using the $\mathrm{EF}_{\mathrm{CO}}$ for the boreal forest from Akagi et al. (2011), whereas the cyan color corresponds to the values of $\mathrm{EF}_{\mathrm{x}}$ calculated using the $\mathrm{EF}_{\mathrm{CO}}$ for the extratropical forest from Andreae and Merlet (2001).

Our $\mathrm{EF}_{\mathrm{HCN}}$ are lower than the two mean values reported in the literature. The sources and sinks of HCN are not well known. Our $\mathrm{EF}_{\mathrm{C}_{2} \mathrm{H}_{6}}$ agree well, within combined error, with the mean value reported by Akagi et al. (2011) and are higher than the mean value reported in the earlier study of Andreae and Merlet (2001). The emission factors of $\mathrm{C}_{2} \mathrm{H}_{2}$ estimated from the FTIR measurements are in excellent agreement with the mean values reported in both compilation studies. Our $\mathrm{EF}_{\mathrm{CH}_{3} \mathrm{OH}}$ are in agreement with the mean value from Akagi et al. (2011) and are higher than the mean value reported by Andreae and Merlet (2001), suggesting that $\mathrm{CH}_{3} \mathrm{OH}$ emissions from fires are higher than previously thought. Finally, our $\mathrm{EF}_{\mathrm{HCOOH}}$ are significantly higher than the values reported in the more recent compilation study of Akagi et 
Table 7. Means and 1-sigma standard deviations of equivalent emission ratios and emission factors (using EFco for the extratropical forest) calculated from FTIR measurements performed at Eureka and Thule for $\mathrm{HCN}, \mathrm{C}_{2} \mathrm{H}_{6}, \mathrm{C}_{2} \mathrm{H}_{2}, \mathrm{CH}_{3} \mathrm{OH}$, and $\mathrm{HCOOH}$. Standard deviations are smaller than in Tables 5 and 6 because filters (using threshold values on the linear correlation coefficient $(r>0.6)$ and the number of points $(N \geq 6))$

\begin{tabular}{lcccc}
\hline & \multicolumn{2}{c}{ Eureka } & \multicolumn{2}{c}{ Thule } \\
& Mean ER \pm SD & Mean EF \pm SD & Mean ER $\pm \mathrm{SD}$ & Mean EF $\pm \mathrm{SD}$ \\
\hline $\mathrm{HCN}$ & $0.00343 \pm 0.00094$ & $0.36 \pm 0.17$ & $0.00429 \pm 0.00245$ & $0.44 \pm 0.25$ \\
$\mathrm{C}_{2} \mathrm{H}_{6}$ & $0.00956 \pm 0.00319$ & $1.09 \pm 0.74$ & $0.01211 \pm 0.00476$ & $1.39 \pm 0.68$ \\
$\mathrm{C}_{2} \mathrm{H}_{2}$ & $0.00405 \pm 0.00174$ & $0.40 \pm 0.25$ & $0.00280 \pm 0.00084$ & $0.28 \pm 0.18$ \\
$\mathrm{CH}_{3} \mathrm{OH}$ & $0.02813 \pm 0.01252$ & $3.44 \pm 1.68$ & & \\
$\mathrm{HCOOH}$ & $0.01531 \pm 0.00403$ & $2.69 \pm 1.14$ & $0.01790 \pm 0.00937$ & $3.15 \pm 1.46$ \\
\hline
\end{tabular}

al. (2011), but agree well with the mean value reported in 2001 (Andreae and Merlet, 2001). This may suggest that fires from the extratropical forest emit relatively large amounts of $\mathrm{HCOOH}$, or it may reflect a local biogenic component in our measurements.

\section{Summary and conclusions}

The frequency and intensity of biomass burning are strongly linked to climate change, and constitute a large source of the variability in Arctic tropospheric composition. We performed FTIR measurements of seven important biomass burning species $\left(\mathrm{CO}, \mathrm{HCN}, \mathrm{C}_{2} \mathrm{H}_{6}, \mathrm{C}_{2} \mathrm{H}_{2}, \mathrm{CH}_{3} \mathrm{OH}, \mathrm{HCOOH}\right.$, and $\mathrm{H}_{2} \mathrm{CO}$ ) at two high Arctic sites, Eureka and Thule, from 2008 to 2012. We focused on these species for several reasons. (1) There remain numerous gaps in the available tropospheric observational data sets, especially at high latitudes. (2) Since these species exhibit different source fractions (anthropogenic, biogenic, fossil fuel burning, and biomass burning), as well as different lifetimes, the comparison of our new data sets with chemical transport model simulations can help identify issues in the model that can be addressed to improve their estimations of trace gas concentrations and temporal variations, as well as transport processes in the high Arctic. (3) All these biomass burning products are measured almost simultaneously using the FTIR technique, so we derived emission factors to add new values to the relatively sparse data sets in the literature.

Those new data sets of tropospheric species recorded at both stations exhibit similar seasonal cycles, in terms of absolute values and temporal variabilities. In addition, ten and eight fire events were identified at Eureka and Thule, respectively. These highlight the importance of the biomass burning long-range transport in the Arctic budget of NMHC, which can affect air quality and climate in this region. This may have a continued and increasing effect in a warming climate and sensitive Arctic ecosystem.

The two sets of measurements were compared with MOZART-4 to assess (1) the general agreement (20082012), (2) the model simulations of the different seasonal cy- cles (with the 2008 year), and (3) fire emissions in the model. Correlations between MOZART-4 and FTIR total columns are strong ( $r$ ranges from 0.35 to 0.93 ). The mean relative differences between MOZART- 4 and the $\mathrm{CO}$ and $\mathrm{HCN}$ measurements confirm the good agreement between the model data and the FTIR observations. In winter, $\mathrm{CO}$ and $\mathrm{C}_{2} \mathrm{H}_{2}$ total columns estimated by MOZART-4 agree well with the FTIR measurements, suggesting that transport is well represented in the model, since it is the major process controlling the Arctic budget of these long tropospheric lifetime gases. However, for $\mathrm{C}_{2} \mathrm{H}_{6}$, the low columns estimated in winter by MOZART-4 confirm an underestimation in its emissions in the model. For HCN, the good agreement in winter also confirms that transport is well reproduced. In spring and summer, however, the overestimation of the model columns suggests that loss processes for $\mathrm{HCN}$ are missing. Finally, the $\mathrm{CH}_{3} \mathrm{OH}$ total columns show good agreement between MOZART-4 and the FTIR data set at Eureka.

In order to estimate emissions from fires, all fire-affected spectra recorded inside smoke plumes were used to calculate the enhancement ratios relative to $\mathrm{CO}$. Very good correlations with $\mathrm{CO}$ are found inside smoke plumes in the Arctic, confirming the common fire origins and transport pathways. $\mathrm{CO}$ and $\mathrm{H}_{2} \mathrm{CO}$ total columns are well correlated $(r>0.9)$ inside fire plumes transported in June 2011 to Thule and in July 2012 to Eureka, suggesting a possible secondary production of $\mathrm{H}_{2} \mathrm{CO}$ in atmospheric smoke plumes. The enhancement ratios were used to derive equivalent emission ratios from which emission factors were calculated using an assumed emission factor for $\mathrm{CO}$. The means of emission factors estimated with the two FTIR data sets are $0.40 \pm 0.21 \mathrm{~g} \mathrm{~kg}^{-1}$ for $\mathrm{HCN}, 1.24 \pm 0.71 \mathrm{~g} \mathrm{~kg}^{-1}$ for $\mathrm{C}_{2} \mathrm{H}_{6}, 0.34 \pm 0.21 \mathrm{~g} \mathrm{~kg}^{-1}$ for $\mathrm{C}_{2} \mathrm{H}_{2}$, and $2.92 \pm 1.30 \mathrm{~g} \mathrm{~kg}^{-1}$ for $\mathrm{HCOOH}$. The emission factor for $\mathrm{CH}_{3} \mathrm{OH}$ estimated at Eureka is $3.44 \pm 1.68 \mathrm{~g} \mathrm{~kg}^{-1}$. These measurements add new observations to the sparse data set of emission factors that have been reported and compiled in the literature.

An extension of this work would be to compare the FTIR measurements to the CAM-chem model (Lamarque et al., 2010), which has online MEGAN biogenic emissions for 
many species, such as methanol and formic acid, to assess how this improves the comparison compared to MOZART-4.

Acknowledgements. This work was supported by NSERC. The PEARL Bruker 125HR measurements at Eureka were made by CANDAC, which has been supported by the AIF/NSRIT, CFI, CFCAS, CSA, EC, Government of Canada IPY funding, NSERC, OIT, ORF, PCSP, and FQRNT. The authors wish to thank the staff at the Eureka Weather Station and CANDAC for the logistical and on-site support provided. Thanks to Rodica Lindenmaier, Rebecca Batchelor, PEARL site manager Pierre Fogal, and CANDAC/PEARL operators Ashley Harrett, Alexei Khmel, Paul Loewen, Keith MacQuarrie, Oleg Mikhailov, and Matt Okraszewski, for their invaluable assistance in maintaining the Bruker 125HR and for taking measurements. The National Center for Atmospheric Research is supported by the National Science Foundation. The observation program at Thule, Greenland, is supported under contract by the National Aeronautics and Space Administration and the site is also supported by the NSF Office of Polar Programs. We wish to thank the Danish Meteorological Institute for support at Thule. The authors also acknowledge NOAA-ARL for access to the HYSPLIT trajectory model, and NASA for its MODIS and OMI imagery products available from their Rapidfire website and from the Giovanni online data system, developed and maintained by the NASA GES DISC. The visit of C. Paton-Walsh to the UofT to collaborate on this study was funded by the ARC as part of project DP110101948.

Edited by: T. von Clarmann

\section{References}

Akagi, S. K., Yokelson, R. J., Wiedinmyer, C., Alvarado, M. J., Reid, J. S., Karl, T., Crounse, J. D., and Wennberg, P. O.: Emission factors for open and domestic biomass burning for use in atmospheric models, Atmos. Chem. Phys., 11, 4039-4072, doi:10.5194/acp-11-4039-2011, 2011.

Akagi, S. K., Craven, J. S., Taylor, J. W., McMeeking, G. R., Yokelson, R. J., Burling, I. R., Urbanski, S. P., Wold, C. E., Seinfeld, J. H., Coe, H., Alvarado, M. J., and Weise, D. R.: Evolution of trace gases and particles emitted by a chaparral fire in California, Atmos. Chem. Phys., 12, 1397-1421, doi:10.5194/acp-12-13972012, 2012.

Amiro, B. D., Cantin, A., Flannigan, M. D., and de Groot, W. J.: Future emissions from Canadian boreal forest fires, Can. J. For. Res., 39, 383-395, doi:10.1139/X08-154, 2009.

Andreae, M. O. and Merlet, P.: Emission of trace gases and aerosols from biomass burning, Global Biogeochem. Cy., 15, 955-966, doi:10.1029/2000GB001382, 2001.

Barrett, C., Kelly, R., Higuera, P. E., and Hu, F. S.: Climatic and land-cover influences on the spatiotemporal dynamics of Holocene boreal fire regimes, Ecology, 94, 389-402, doi:10.1890/12-0840.1, 2013.

Bian, H., Colarco, P. R., Chin, M., Chen, G., Rodriguez, J. M., Liang, Q., Blake, D., Chu, D. A., da Silva, A., Darmenov, A. S., Diskin, G., Fuelberg, H. E., Huey, G., Kondo, Y., Nielsen, J. E.,
Pan, X., and Wisthaler, A.: Source attributions of pollution to the Western Arctic during the NASA ARCTAS field campaign, Atmos. Chem. Phys., 13, 4707-4721, doi:10.5194/acp-13-47072013, 2013.

Coffey, M. T., Goldman, A., Hannigan, J. W., Mankin, W. G., Schoenfeld, W. G., Rinsland, C. P., Bernardo, C., and Griffith, D. W. T.: Improved vibration-rotation (0-1) HBr line parameters for validating high resolution infrared atmospheric spectra measurements, J. Quant. Spectrosc. Radiat. Transf., 60, 863-867, doi:10.1016/S0022-4073(98)00088-0, 1998.

Coheur, P.-F., Herbin, H., Clerbaux, C., Hurtmans, D., Wespes, C., Carleer, M., Turquety, S., Rinsland, C. P., Remedios, J., Hauglustaine, D., Boone, C. D., and Bernath, P. F.: ACE-FTS observation of a young biomass burning plume: first reported measurements of $\mathrm{C}_{2} \mathrm{H}_{4}, \mathrm{C}_{3} \mathrm{H}_{6} \mathrm{O}, \mathrm{H}_{2} \mathrm{CO}$ and PAN by infrared occultation from space, Atmos. Chem. Phys., 7, 5437-5446, doi:10.5194/acp-75437-2007, 2007.

Coheur, P.-F., Clarisse, L., Turquety, S., Hurtmans, D., and Clerbaux, C.: IASI measurements of reactive trace species in biomass burning plumes, Atmos. Chem. Phys., 9, 5655-5667, doi:10.5194/acp-9-5655-2009, 2009.

Colarco, P. R., Schoeberl, M. R., Doddridge, B. G., Marufu, L. T., Torres, O., and Welton, E. J.: Transport of smoke from Canadian forest fires to the surface near Washington, D. C.: Injection height, entrainment, and optical properties, J. Geophys. Res., 109, D06203, doi:10.1029/2003JD004248, 2004.

Daniel, J. S. and Solomon, S.: On the climate forcing of carbon monoxide, J. Geophys. Res., 103, 13249-13260, doi:10.1029/98JD00822, 1998.

Eckhardt, S., Stohl, A., Beirle, S., Spichtinger, N., James, P., Forster, C., Junker, C., Wagner, T., Platt, U., and Jennings, S. G.: The North Atlantic Oscillation controls air pollution transport to the Arctic, Atmos. Chem. Phys., 3, 1769-1778, doi:10.5194/acp3-1769-2003, 2003.

Emmons, L. K., Arnold, S., Monks, S., Huijnen, V., Tilmes, S., Law, K., Thomas, J. L., Raut, J.-C., Bouarar, I., Turquety, S., Long, Y., Duncan, B., Steenrod, S., Strode, S., Flemming, J., Mao, J., Langner, J., Thompson, A. M., Tarasick, D., Apel, E., Blake, D., Brune, W., Cohen, R. C., Dibb, J., Diskin, G. S., Fried, A., Hall, S., Huey, G., Weinheimer, A. J., Wennberg, P., Wisthaler, A., Mikoviny, T., de Gouw, J., Holloway, J., Montzka, S., Nowak, J., Peischl, J., Roberts, J., Ryerson, T., Warneke, C., and Helmig, D.: The POLARCAT Model Intercomparison Project (POLMIP): Overview and evaluation with observations, Atmos. Chem. Phys. Discuss., 14, 29331-29393, doi:10.5194/acpd-14-29331-2014, 2014.

Emmons, L. K., Walters, S., Hess, P. G., Lamarque, J.-F., Pfister, G. G., Fillmore, D., Granier, C., Guenther, A., Kinnison, D., Laepple, T., Orlando, J., Tie, X., Tyndall, G., Wiedinmyer, C., Baughcum, S. L., and Kloster, S.: Description and evaluation of the Model for Ozone and Related chemical Tracers, version 4 (MOZART-4), Geosci. Model Dev., 3, 43-67, doi:10.5194/gmd3-43-2010, 2010.

Eyring, V., Waugh, D. W., Bodeker, G. E., Cordero, E., Akiyoshi, H., Austin, J., Beagley, S. R., Boville, B. A., Braesicke, P., Brühl, C., Butchart, N., Chipperfield, M. P., Dameris, M., Deckert, R., Deushi, M., Frith, S. M., Garcia, R. R., Gettelman, A., Giorgetta, M. A., Kinnison, D. E., Mancini, E., Manzini, E., Marsh, D. R., Matthes, S., Nagashima, T., Newman, P. A., Nielsen, J. E., Paw- 
son, S., Pitari, G., Plummer, D. A., Rozanov, E., Schraner, M., Scinocca, J. F., Semeniuk, K., Shepherd, T. G., Shibata, K., Steil, B., Stolarski, R. S., Tian W., and Yoshiki, M.: Multi-model projections of stratospheric ozone in the 21st century, J. Geophys. Res. , 112, D16303, doi:10.1029/2006JD008332, 2007.

Finch, D. P., Palmer, P. I., and Parrington, M.: Origin, variability and age of biomass burning plumes intercepted during BORTASB: evidence for retardation of plume photochemistry, Atmos. Chem. Phys. Discuss., 14, 8723-8752, doi:10.5194/acpd-148723-2014, 2014.

Fisher, J. A., Jacob, D. J., Purdy, M. T., Kopacz, M., Le Sager, P., Carouge, C., Holmes, C. D., Yantosca, R. M., Batchelor, R. L., Strong, K., Diskin, G. S., Fuelberg, H. E., Holloway, J. S., Hyer, E. J., McMillan, W. W., Warner, J., Streets, D. G., Zhang, Q., Wang, Y., and Wu, S.: Source attribution and interannual variability of Arctic pollution in spring constrained by aircraft (ARCTAS, ARCPAC) and satellite (AIRS) observations of carbon monoxide, Atmos. Chem. Phys., 10, 977-996, doi:10.5194/acp-10-977-2010, 2010.

Flannigan, M., Stocks, B., Turetsky, M., and Wotton, M.: Impacts of climate change on fire activity and fire management in the circumboreal forest, Glob. Change Biol., 15, 549-60, doi:10.1111/j.1365-2486.2008.01660.x, 2009.

Fogal, P. F., LeBlanc, L. M., and Drummond, J. R.: The Polar Environment Atmospheric Research Laboratory (PEARL): sounding the atmosphere at $80^{\circ}$ North, Arctic, 66, 377-386, doi:10.1175/2009JTECHA1215.1, 2013.

Garcia, R. R., Marsh, D. R., Kinnison, D. E., Boville, B. A., and Sassi, F.: Simulation of secular trends in the middle atmosphere, 1950-2003, J. Geophys. Res., 112, D09301, doi:10.1029/2006JD007485, 2007.

Generoso, S., Breon, F., Chevallier, F., Balkanski, Y., Schulz, M., and Bey, I.: Assimilation of POLDER aerosol optical thickness into the LMDz-INCA model: implications for the Arctic aerosol burden, J. Geophys. Res., 112, D02311, doi:10.1029/2005JD006954, ISSN: 0148-0227, 2007.

Gerbig, C., Lin, J. C., Wofsy, S. C., Daube, B. C., Andrews, A. E., Stephens, B. B., Bakwin, P. S., and Grainger, C. A.: Toward constraining regional-scale fluxes of $\mathrm{CO} 2$ with atmospheric observations over a continent: 2. Analysis of COBRA data using a receptor-oriented framework, J. Geophys. Res.-Atmos., 108, D24, 4757, doi:10.1029/2003JD003770, 2003

Goldman, A., Paton-Walsh, C., Bell, W., Toon, G. C., Blavier, J. F., Sen, B., Coffey, M. T., Hannigan, J. W., and Mankin, W. G.: Network for the detection of stratospheric change Fourier transform infrared intercomparison at Table Mountain Facility, J. Geophys. Res., 104, 30481-30503, doi:10.1029/1999JD900879, 1999.

Hannigan, J. W., Coffey, M. T., and Goldman, A.: Semiautonomous FTS Observation System for Remote Sensing of Stratospheric and Tropospheric Gases, J. Atmos. Oceanic Technol., 26, 18141828, doi:10.1175/2009JTECHA1230.1, 2009.

Hecobian, A., Liu, Z., Hennigan, C. J., Huey, L. G., Jimenez, J. L., Cubison, M. J., Vay, S., Diskin, G. S., Sachse, G. W., Wisthaler, A., Mikoviny, T., Weinheimer, A. J., Liao, J., Knapp, D. J., Wennberg, P. O., Kürten, A., Crounse, J. D., St. Clair, J., Wang, Y., and Weber, R. J.: Comparison of chemical characteristics of 495 biomass burning plumes intercepted by the NASA DC-8 aircraft during the ARCTAS/CARB-2008 field campaign,
Atmos. Chem. Phys., 11, 13325-13337, doi:10.5194/acp-1113325-2011, 2011.

Hornbrook, R. S., Blake, D. R., Diskin, G. S., Fried, A., Fuelberg, H. E., Meinardi, S., Mikoviny, T., Richter, D., Sachse, G. W. Vay, S. A., Walega, J., Weibring, P., Weinheimer, A. J., Wiedinmyer, C., Wisthaler, A., Hills, A., Riemer, D. D., and Apel, E. C.: Observations of nonmethane organic compounds during ARCTAS - Part 1: Biomass burning emissions and plume enhancements, Atmos. Chem. Phys., 11, 11103-11130, doi:10.5194/acp11-11103-2011, 2011.

Hurst, D. F., Griffith, D. W. T., and Cook, G. D.: Trace gas emissions from biomass burning in tropical Australian savannas, J. Geophys. Res., 99, 16441-16456, doi:10.1029/94JD00670, 1994.

IPCC: Climate Change 2007: The Physical Science Basis, edited by: Solomon, S., Quin, D., Manning, M., Chen, Z., Marquis, M., Averyt, K. B., Tignor, M., and Miller, H. L., 500-657, Cambridge University Press, Cambridge, United Kingdom, USA, 2007.

Kasischke, E. S. and Turetsky, M. R.: Recent changes in the fire regime across the North American boreal region - Spatial and temporal patterns of burning across Canada and Alaska, Geophys. Res. Let., 33, L09703, doi:10.1029/2006GL025677, 2006.

Kelly, R., Chipmanb, M. L., Higuerac, P. E., Stefanovad, I., Brubakere, L. B., and Hu, F. S.: Recent burning of boreal forests exceeds fire regime limits of the past 10000 years, PNAS, 110, 13055-13060, doi:10.1073/pnas.1305069110, 2013.

Koch, D. and Hansen, J.: Distant origins of Arctic black carbon: A Goddard Institute for Space Studies Model experiment, J. Geophys. Res., 110, D04204, doi:10.1029/2004JD005296, 2005.

Kurylo, M. J.: Network for the detection of stratospheric change (NDSC), P. Soc. Photo-Opt. Inst., 1491, 168-174, 1991.

Kurylo, M. J. and Zander R.: The NDSC - its status after 10 years of operation. Proceedings of the XIX Quadrennial Ozone Symposium, Hokkaido Univ., Sapporo, Japan on 3-8 July 2000, 167 168, 2000.

Lamarque, J.-F., Emmons, L. K., Hess, P. G., Kinnison, D. E., Tilmes, S., Vitt, F., Heald, C. L., Holland, E. A., Lauritzen, P. H., Neu, J., Orlando, J. J., Rasch, P. J., and Tyndall, G. K.: CAMchem: description and evaluation of interactive atmospheric chemistry in the Community Earth System Model, Geosci. Model Dev., 5, 369-411, doi:10.5194/gmd-5-369-2012, 2012.

Le Breton, M., Bacak, A., Muller, J. B. A., O’Shea, S. J., Xiao, P., Ashfold, M. N. R., Cooke, M. C., Batt, R., Shallcross, D. E., Oram, D. E., Forster, G., Bauguitte, S. J.-B., and Percival, C. J.: Airborne HCN measurements from biomass burning, Atmos. Chem. Phys., 13, 9217-9232, doi:10.5194/acp-13-92172013, 2013.

Lesins, G., Duck T. J., and Drummond, J. R.: Climate trends at Eureka in the Canadian high Arctic, Atmos. Ocean, 48, 59-80, doi:10.3137/AO1103.2010, 2010.

Lewis, A. C., Evans, M. J., Hopkins, J. R., Punjabi, S., Read, K. A., Purvis, R. M., Andrews, S. J., Moller, S. J., Carpenter, L. J., Lee, J. D., Rickard, A. R., Palmer, P. I., and Parrington, M.: The influence of biomass burning on the global distribution of selected non-methane organic compounds, Atmos. Chem. Phys., 13, 851867, doi:10.5194/acp-13-851-2013, 2013.

Li, Q., Jacob, D. J., Yantosca, R. M., Heald, C. L., Singh, H. B., Koike, M., Zhao, Y., Sachse, G. W., and Streets, D. G.: A global three-dimensional model analysis of the atmospheric budgets of $\mathrm{HCN}$ and $\mathrm{CH}_{3} \mathrm{CN}$ : Constraints from air- 
craft and ground measurements, J. Geophys. Res., 108, 8827, doi:10.1029/2002JD003075, 2003.

Lin, J. C., Gerbig, C., Wofsy, S. C., Andrews, A. E., Daube, B. C., Davis, K. J., and Grainger, C. A.: A near-field tool for simulating the upstream influence of atmospheric observations: the Stochastic Time-Inverted Lagrangian Transport (STILT) model, J. Geophys. Res., 108, 4493, doi:10.1029/2002JD003161, 2003.

Mao, J., Jacob, D. J., Evans, M. J., Olson, J. R., Ren, X., Brune, W. H., Clair, J. M. St., Crounse, J. D., Spencer, K. M., Beaver, M. R., Wennberg, P. O., Cubison, M. J., Jimenez, J. L., Fried, A., Weibring, P., Walega, J. G., Hall, S. R., Weinheimer, A. J., Cohen, R. C., Chen, G., Crawford, J. H., McNaughton, C., Clarke, A. D., Jaeglé, L., Fisher, J. A., Yantosca, R. M., Le Sager, P., and Carouge, C.: Chemistry of hydrogen oxide radicals $\left(\mathrm{HO}_{\mathrm{x}}\right)$ in the Arctic troposphere in spring, Atmos. Chem. Phys., 10, 5823-5838, doi:10.5194/acp-10-58232010, 2010.

Olson, D. M., Dinerstein, E., Wikramanayake, E. D., Burgess, N. D., Powell, G. V. N., Underwood, E. C., D'Amico, J. A., I. Itoua, Strand, H. E., Morrison, J. C., Loucks, C. J., Allnutt, T. F., Ricketts, T. H., Kura, Y., Lamoreux, J. F., Wettengel, W. W., Hedao, P., and Kassem, K. R.: Terrestrial ecoregions of the world: new map of life on earth, Bioscience, 51, 933-938, 2001.

Olson, J. R., Crawford, J. H., Brune, W., Mao, J., Ren, X., Fried, A., Anderson, B., Apel, E., Beaver, M., Blake, D., Chen, G., Crounse, J., Dibb, J., Diskin, G., Hall, S. R., Huey, L. G., Knapp, D., Richter, D., Riemer, D., St. Clair, J., Ullmann, K., Walega, J., Weibring, P., Weinheimer, A., Wennberg, P. O., and Wisthaler, A.: An analysis of fast photochemistry over high northern latitudes during spring and summer using in-situ observations from ARCTAS and TOPSE, Atmos. Chem. Phys., 12, 67996825, doi:10.5194/acp-12-6799-2012, 2012.

O’Neill, N. T., Pancrati, O., Baibakov, K., Eloranta, E., Batchelor, R. L., Freemantle, J., and Lindenmaier, R.: Occurrence of weak, submicron, tropospheric aerosol events at high Arctic latitudes, Geophys. Res. Let., 35, L14814, doi:10.1029/2008GL033733, 2008.

Oris, F., Asselin, H., Ali, A. A., Finsinger, W., and Bergeron, Y.: Effect of increased fire activity on global warming in the boreal forest, Environ. Rev., 22, 206-219, doi:10.1139/er-2013-0062, 2013.

O'Shea, S. J., Allen, G., Gallagher, M. W., Bauguitte, S. J.-B., Illingworth, S. M., Le Breton, M., Muller, J. B. A., Percival, C. J., Archibald, A. T., Oram, D. E., Parrington, M., Palmer, P. I., and Lewis, A. C.: Airborne observations of trace gases over boreal Canada during BORTAS: campaign climatology, air mass analysis and enhancement ratios, Atmos. Chem. Phys., 13, 1245112467, doi:10.5194/acp-13-12451-2013, 2013.

Palmer, P. I., Parrington, M., Lee, J. D., Lewis, A. C., Rickard, A. R., Bernath, P. F., Duck, T. J., Waugh, D. L., Tarasick, D. W., Andrews, S., Aruffo, E., Bailey, L. J., Barrett, E., Bauguitte, S. J.B., Curry, K. R., Di Carlo, P., Chisholm, L., Dan, L., Forster, G., Franklin, J. E., Gibson, M. D., Griffin, D., Helmig, D., Hopkins, J. R., Hopper, J. T., Jenkin, M. E., Kindred, D., Kliever, J., Le Breton, M., Matthiesen, S., Maurice, M., Moller, S., Moore, D. P., Oram, D. E., O'Shea, S. J., Owen, R. C., Pagniello, C. M. L. S., Pawson, S., Percival, C. J., Pierce, J. R., Punjabi, S., Purvis, R. M., Remedios, J. J., Rotermund, K. M.,
Sakamoto, K. M., da Silva, A. M., Strawbridge, K. B., Strong, K., Taylor, J., Trigwell, R., Tereszchuk, K. A., Walker, K. A., Weaver, D., Whaley, C., and Young, J. C.: Quantifying the impact of BOReal forest fires on Tropospheric oxidants over the Atlantic using Aircraft and Satellites (BORTAS) experiment: design, execution and science overview, Atmos. Chem. Phys., 13, 6239-6261, doi:10.5194/acp-13-6239-2013, 2013.

Paris, J.-D., Stohl, A., Nédélec, P., Arshinov, M. Yu., Panchenko, M. V., Shmargunov, V. P., Law, K. S., Belan, B. D., and Ciais, P.: Wildfire smoke in the Siberian Arctic in summer: source characterization and plume evolution from airborne measurements, Atmos. Chem. Phys., 9, 9315-9327, doi:10.5194/acp-9-9315-2009, 2009.

Parrington, M., Palmer, P. I., Lewis, A. C., Lee, J. D., Rickard, A. R., Di Carlo, P., Taylor, J. W., Hopkins, J. R., Punjabi, S., Oram, D. E., Forster, G., Aruffo, E., Moller, S. J., Bauguitte, S. J.B., Allan, J. D., Coe, H., and Leigh, R. J.: Ozone photochemistry in boreal biomass burning plumes, Atmos. Chem. Phys., 13, 7321-7341, doi:10.5194/acp-13-7321-2013, 2013.

Paton-Walsh, C., Jones, N. B., Wilson, S. R., Harverd, V., Meier, A., Griffith, D. W. T., and Rinsland, C. P.: Measurements of trace gas emissions from Australian forest fires and correlations with coincident measurements of aerosol optical depth, J. Geophys. Res., 110, D24305, doi:10.1029/2005JD006202, 2005.

Paton-Walsh, C., Wilson, S. R., Jones, N. B., and Griffith, D. W. T.: Measurement of methanol emissions from Australian wildfires by ground-based solar Fourier transform spectroscopy, Geophys. Res. Lett., 35, L08810, doi:10.1029/2007GL032951, 2008.

Paton-Walsh, C., Deutscher, N. M., Griffith, D. W. T., Forgan, B. W., Wilson, S. R., Jones, N. B., and Edwards, D. P.: Trace gas emissions from savanna fires in Northern Australia, J. Geophys. Res., 115, D16314, doi:10.1029/2009JD013309, 2010.

Paulot, F., Wunch, D., Crounse, J. D., Toon, G. C., Millet, D. B., DeCarlo, P. F., Vigouroux, C., Deutscher, N. M., Gonzalez Abad, G., Notholt, J., Warneke, T., Hannigan, J. W., Warneke, C., de Gouw, J. A., Dunlea, E. J., De Maziere, M., Griffith, D. W. T., Bernath, P., Jimenez, J. L., and Wennberg, P. O.: Importance of secondary sources in the atmospheric budgets of formic and acetic acids, Atmos. Chem. Phys., 11, 1989-2013, doi:10.5194/acp-11-1989-2011, 2011.

Rinsland, C., Dufour, G., Boone, C., Bernath, P., Chiou, L., Coheur, P., Turquety, S., and Clerbaux, C.: Satellite boreal measurements over Alaska and Canada during June-July 2004: Simultaneous measurements of upper tropospheric $\mathrm{CO}, \mathrm{C}_{2} \mathrm{H}_{6}$, $\mathrm{HCN}, \mathrm{CH}_{3} \mathrm{Cl}, \mathrm{CH}_{4}, \mathrm{C}_{2} \mathrm{H}_{2}, \mathrm{CH}_{3} \mathrm{OH}, \mathrm{HCOOH}, \mathrm{OCS}$, and $\mathrm{SF}_{6}$ mixing ratios, Global Biogeochem. Cy., 21, GB3008, doi:10.1029/2006GB002795, 2007.

Rodgers, C. D.: Inverse methods for atmospheric sounding theory and practise, in: Series on Atmospheric, Oceanic and Planetary Physics, Vol. 2, World Scientific, London, 238 pp., 2000.

Rodgers, C. D. and Connor, B. J.: Intercomparison of remote sounding instruments, J. Geophys. Res., 108, 4116-4129, doi:10.1029/2002JD002299, 2003.

Rothman, L. S., Gordon, I. E., Barbe, A., Benner, D. C., Bernath, P. F., Birk, M., Boudon, V., Brown, L. R., Campargue, A., Champion, J.-P., Chance, K., Coudert, L. H., Danaj, V., Devi, V. M., Fally, S., Flaud, J.-M., Gamache, R. R., Goldmanm, A., Jacquemart, D., Kleiner, I., Lacome, N., Lafferty, W. J., Mandin, J.-Y., Massie, S. T., Mikhailenko, S. N., Miller, C. E., 
Moazzen-Ahmadi, N., Naumenko, O. V., Nikitin, A. V., Orphal, J., Perevalov, V. I., Perrin, A., Predoi-Cross, A., Rinsland, C. P., Rotger, M., Simeckova, M., Smith, M. A. H., Sung, K., Tashkun, S. A., Tennyson, J., Toth, R. A., Vandaele, A. C., and Vander Auwera, J.: The Hitran 2008 molecular spectroscopic database, J. Quant. Spectrosc. Radiat. Transfer, 110, 533-572, doi:10.1016/j.jqsrt.2009.02.013, 2009.

Saha, A., O’Neill, N. T., Eloranta, E., Stone, R. S., Eck, T. F., Zidane, S., McArthur, L. J. B.: Pan-Arctic sunphotometry during the ARCTAS-A campaign of April 2008, Geophys. Res. Lett., 37, L05803, doi:10.1029/2009GL041375, 2010.

Shindell, D. T., Chin, M., Dentener, F., Doherty, R. M., Faluvegi, G., Fiore, A. M., Hess, P., Koch, D. M., MacKenzie, I. A., Sanderson, M. G., Schultz, M. G., Schulz, M., Stevenson, D. S., Teich, H., Textor, C., Wild, O., Bergmann, D. J., Bey, I., Bian, H., Cuvelier, C., Duncan, B. N., Folberth, G., Horowitz, L. W., Jonson, J., Kaminski, J. W., Marmer, E., Park, R., Pringle, K. J., Schroeder, S., Szopa, S., Takemura, T., Zeng, G., Keating, T. J., and Zuber, A.: A multi-model assessment of pollution transport to the Arctic, Atmos. Chem. Phys., 8, 5353-5372, doi:10.5194/acp-85353-2008, 2008.

Simpson, I. J., Akagi, S. K., Barletta, B., Blake, N. J., Choi, Y., Diskin, G. S., Fried, A., Fuelberg, H. E., Meinardi, S., Rowland, F. S., Vay, S. A., Weinheimer, A. J., Wennberg, P. O., Wiebring, P., Wisthaler, A., Yang, M., Yokelson, R. J., and Blake, D. R.: Boreal forest fire emissions in fresh Canadian smoke plumes: $\mathrm{C}_{1}-\mathrm{C}_{10}$ volatile organic compounds (VOCs), $\mathrm{CO}_{2}, \mathrm{CO}, \mathrm{NO}_{2}, \mathrm{NO}, \mathrm{HCN}$ and $\mathrm{CH}_{3} \mathrm{CN}$, Atmos. Chem. Phys., 11, 6445-6463, doi:10.5194/acp-11-6445-2011, 2011.

Soja, A. J., Tchebakova, N. M., French, N. H. F., Flannigan, M. D., Shugart, H. H., Stocks, B. J., Sukhinin, A. I., Parfenova, E. I., Chapin, F. S., and Stackhouse, P. W.: Climate-induced boreal forest change: predictions vs. current observations, Global Planet. Change, 56, 274-296, doi:10.1016/j.gloplacha.2006.07.028, 2007.

Stavrakou, T., Müller, J.-F., De Smedt, I., Van Roozendael, M., van der Werf, G. R., Giglio, L., and Guenther, A.: Evaluating the performance of pyrogenic and biogenic emission inventories against one decade of space-based formaldehyde columns, Atmos. Chem. Phys., 9, 1037-1060, doi:10.5194/acp-9-1037-2009, 2009.

Stavrakou, T., Müller, J.-F., Peeters, J., Razavi, A., Clarisse, L., Clerbaux, C., Coheur, P.-F., Hurtmans, D., De Mazière, M., Vigouroux, C., Deutscher, N. M., Griffith, D. W. T., Jones, N., and Paton-Walsh, C.: Satellite evidence for a large source of formic acid from boreal and tropical forests, Nat. Geosci., 5, 2630, doi:10.1038/ngeo1354, 2012.

Stohl, A.: Characteristics of atmospheric transport into the Arctic troposphere, J. Geophys. Res., 111, D11306, doi:10.1029/2005JD006888, 2006.

Stohl, A., Berg, T., Burkhart, J. F., Fjæraa, A. M., Forster, C., Herber, A., Hov, Ø., Lunder, C., McMillan, W. W., Oltmans, S., Shiobara, M., Simpson, D., Solberg, S., Stebel, K., Strom, J., Tørseth, K., Treffeisen, R., Virkkunen, K., and Yttri, K. E.: Arctic smokerecord air pollution levels in the European Arcticduring a period of abnormal warmth, due to agricultural fires in Eastern Europe, Atmos. Chem. Phys., 7, 511-534, doi:10.5194/acp-7-511-2007, 2007.
Tereszchuk, K. A., González Abad, G., Clerbaux, C., Hurtmans, D., Coheur, P.-F., and Bernath, P. F.: ACE-FTS measurements of trace species in the characterization of biomass burning plumes, Atmos. Chem. Phys., 11, 12169-12179, doi:10.5194/acp-1112169-2011, 2011.

Tereszchuk, K. A., González Abad, G., Clerbaux, C., HadjiLazaro, J., Hurtmans, D., Coheur, P.-F., and Bernath, P. F.: ACEFTS observations of pyrogenic trace species in boreal biomass burning plumes during BORTAS, Atmos. Chem. Phys., 13, 4529-4541, doi:10.5194/acp-13-4529-2013, 2013.

Thomas, J. L., Raut, J.-C., Law, K. S., Marelle, L., Ancellet, G., Ravetta, F., Fast, J. D., Pfister, G., Emmons, L. K., Diskin, G. S., Weinheimer, A., Roiger, A., and Schlager, H.: Pollution transport from North America to Greenland during summer 2008, Atmos. Chem. Phys., 13, 3825-3848, doi:10.5194/acp-13-38252013, 2013.

Tilmes, S., Emmons, L. K., Law, K. S., Ancellet, G., Schlager, H., Paris, J.-D., Fuelberg, H. E., Streets, D. G., Wiedinmyer, C., Diskin, G. S., Kondo, Y., Holloway, J., Schwarz, J. P., Spackman, J. R., Campos, T., Ndlec, P., and Panchenko, M V.: Source contributions to Northern Hemisphere CO and black carbon during spring and summer 2008 from POLARCAT and START08/preHIPPO observations and MOZART-4, Atmos. Chem. Phys. Discuss., 11, 5935-5983, doi:10.5194/acpd-115935-2011, 2011.

Viatte, C., Strong, K., Paton-Walsh, C., Mendonca, J., O’Neill, N. T., and Drummond, J. R.: Measurements of CO, $\mathrm{HCN}$ and $\mathrm{C}_{2} \mathrm{H}_{6}$ total columns in smoke plumes transported from the 2010 Russian boreal forest fires to the Canadian high Arctic, AtmosphereOcean, 51, 1-10, doi:10.1080/07055900.2013.823373, 2013.

Viatte, C., Strong, K., Walker, K. A., and Drummond J. R.: Five years of $\mathrm{CO}, \mathrm{HCN}, \mathrm{C}_{2} \mathrm{H}_{6}, \mathrm{C}_{2} \mathrm{H}_{2}, \mathrm{CH}_{3} \mathrm{OH}, \mathrm{HCOOH}$, and $\mathrm{H}_{2} \mathrm{CO}$ total columns measured in the Canadian High Arctic, Atmos. Meas. Tech., 7, 1547-1570, doi:10.5194/amt-7-1547-2014, 2014.

Vigouroux, C., Stavrakou, T., Whaley, C., Dils, B., Duflot, V., Hermans, C., Kumps, N., Metzger, J.-M., Scolas, F., Vanhaelewyn, G., Müller, J.-F., Jones, D. B. A., Li, Q., and De Mazière, M.: FTIR time-series of biomass burning products $\left(\mathrm{HCN}, \mathrm{C}_{2} \mathrm{H}_{6}\right.$, $\mathrm{C}_{2} \mathrm{H}_{2}, \mathrm{CH}_{3} \mathrm{OH}$, and $\left.\mathrm{HCOOH}\right)$ at Reunion Island $\left(21^{\circ} \mathrm{S}, 55^{\circ} \mathrm{E}\right)$ and comparisons with model data, Atmos. Chem. Phys., 12, 10367-10385, doi:10.5194/acp-12-10367-2012, 2012.

Warneke, C., Bahreini, R., Brioude, J., Brock, C. A., de Gouw, J. A., Fahey, D. W., Froyd, K. D., Holloway, J. S., Middlebrook, A., Miller, L., Montzka, S., Murphy, D. M., Peischl, J., Ryerson, T. B., Schwarz, J. P., Spackman, J. R., and Veres, P.: Biomass burning in Siberia and Kazakhstan as an important source for haze over the Alaskan Arctic in April 2008, Geophys. Res. Lett., 36, L02813, doi:10.1029/2008GL036194, 2009.

Wang, Q., Jacob, D. J., Fisher, J. A., Mao, J., Leibensperger, E. M., Carouge, C. C., Le Sager, P., Kondo, Y., Jimenez, J. L., Cubison, M. J., and Doherty, S. J.: Sources of carbonaceous aerosols and deposited black carbon in the Arctic in winter-spring: implications for radiative forcing, Atmos. Chem. Phys., 11, 1245312473, doi:10.5194/acp-11-12453-2011, 2011.

Wiedinmyer, C., Akagi, S. K., Yokelson, R. J., Emmons, L. K., AlSaadi, J. A., Orlando, J. J., and Soja, A. J.: The Fire INventory from NCAR (FINN): a high resolution global model to estimate 
the emissions from open burning, Geosci. Model Dev., 4, 625641, doi:10.5194/gmd-4-625-2011, 2011.

Xiao, Y., Jacob, D. J., and Turquety, S.: Atmospheric acetylene and its relationship with $\mathrm{CO}$ as an indicator of air mass age, J. Geophys. Res., 112, D12305, doi:10.1029/2006JD008268, 2007.

Xiao, Y., Logan, J. A., Jacob, D. J., Hudman, R. C., Yantosca, R., and Blake, D. R.: Global budget of ethane and regional constraints on US sources, J. Geophys. Res., 113, D21306, doi:10.1029/2007JD009415, 2008.

Yokelson, R. J., Andreae, M. O., and Akagi, S. K.: Pitfalls with the use of enhancement ratios or normalized excess mixing ratios measured in plumes to characterize pollution sources and aging, Atmos. Meas. Tech., 6, 2155-2158, doi:10.5194/amt-62155-2013, 2013.

York, D., Evensen, N. M., Lopez Martinez, M., and De Basabe Delgado, J.: Unified equations for the slope, intercept, and standard errors of the best straight line, Am. J. Phys., 72, 367-375, doi:10.1119/1.1632486, 2004.

Young, E. and Paton-Walsh, C.: Emission Ratios of the Tropospheric Ozone Precursors Nitrogen Dioxide and Formaldehyde from Australia's Black Saturday Fires, Atmosphere, 2, 617-632, doi:10.3390/atmos2040617, 2011.
Yurganov, L. N., Blumenstock, T., Grechko, E. I., Hase, F., Hyer, E. J., Kasischke, E. S., Koike, M., Kondo, Y., Kramer, I., Leung, F.-Y., Mahieu, E., Mellqvist, J., Notholt, J., Novelli, P. C., Rinsland, C. P., Scheel, H. E., Schulz, A., Strandberg, A., Sussmann, R., Tanimoto, H., Velazco, V., Zander, R., and Zhao, Y.: A quantitative assessment of the 1998 carbon monoxide emission anomaly in the Northern Hemisphere based on total column and surface concentration measurements, J. Geophys. Res., 109, D15305, doi:10.1029/2004JD004559, 2004.

Yurganov, L. N., Duchatelet, P., Dzhola, A. V., Edwards, D. P., Hase, F., Kramer, I., Mahieu, E., Mellqvist, J., Notholt, J., Novelli, P. C., Rockmann, A., Scheel, H. E., Schneider, M., Schulz, A., Strandberg, A., Sussmann, R., Tanimoto, H., Velazco, V., Drummond, J. R., and Gille, J. C.: Increased Northern Hemispheric carbon monoxide burden in the troposphere in 2002 and 2003 detected from the ground and from space, Atmos. Chem. Phys., 5, 563-573, 2005, http://www.atmos-chem-phys.net/5/563/2005/.

Zeng, G., Wood, S. W., Morgenstern, O., Jones, N. B., Robinson, J., and Smale, D.: Trends and variations in $\mathrm{CO}, \mathrm{C}_{2} \mathrm{H}_{6}$, and $\mathrm{HCN}$ in the Southern Hemisphere point to the declining anthropogenic emissions of $\mathrm{CO}$ and $\mathrm{C}_{2} \mathrm{H}_{6}$, Atmos. Chem. Phys., 12, 75437555, doi:10.5194/acp-12-7543-2012, 2012. 